\title{
A KÖZÖSSÉGI TUDOMÁNY
}

\section{GAÁlnÉ KALYdy DÓRA}

Az Open Science (nyílt tudomány) mozgalom egyre nagyobb teret hódít magának. Míg pár éve még csak a nyílt hozzáférésről beszéltünk (2002, Budapest Open Access Initiative), ma már szerte a világon nyílt tudományról van szó, melynek csupán egy szelete a nyílt hozzáférés. A LIBER ${ }^{1}$ (Association of European Research Libraries) 2021. éves konferenciáján ${ }^{2}$ az előadások és workshopok 55\%-a nyílt tudományhoz kapcsolódtak. Aplenáris előadások szintén a nyílt tudomány témakörben mutattak be újabb és újabb lehetőségeket. A 2019-es konferencián alakult Citizen Science munkabizottság ${ }^{3}$ is bemutatta az elmúlt két év munkáját, a szakkönyvtárak, egyetemi könyvtárak Citizen Science-ben, azaz a közösségi tudományban betöltött szerepét és lehetőségeit és a jó gyakorlatok mentén igyekszik útmutatót adni a könyvtáraknak.

Izgalmas, kérdésekkel teli témának tűnik a közösségi tudomány. A Citizen Science fordítása/magyarosítása nem egyszerű, hiszen a „citizen” állampolgárt jelent, de az „állampolgári vagy polgári tudomány, tudományosság" nem adja vissza azt a frappáns angol kifejezést, mely arra utal, hogy egy tudományos kutatásban nem hivatásos kutatók is, azaz elkötelezett és érdeklődő amatőrök hatékonyan vesznek részt. Az amatőr szó a magyar nyelvben pejoratív értelemmel bír, ezért én magam inkább a közösségi tudomány kifejezést használom.

Mivel Magyarországon hivatalos dokumentumokban nem rögzítették, hogy pontosan mi is a közösségi tudomány, ezért kiindulási pontnak

1 LIBER (Association of European Research Libraries) honlapja: https://libereurope.eu/ (utolsó megtekintés: 2021. 07. 02.)

2 LIBER 2021 ONLINE: https://liberconference.eu/home-2/liber-2021programme/ (utolsó megtekintés: 2021. 07. 02.)

3 LIBER stratégia: https://libereurope.eu/strategy/innovative-scholarlycommunication/citizenscience/ (utolsó megtekintés: 2021. 07. 02.) 
tekintsük a University College London által kiadott Citizen Science ${ }^{4}$ könyvben megfogalmazottakat, mely hivatkozik az Európai Bizottság meghatározására is ${ }^{5}$. Ennek értelmében a közösségi tudomány olyan tudományos munka, melyben részt vesznek a közösség tagjai is, szakemberek és tudományos intézmények irányítása alatt. Ezt a meghatározást az Európai Bizottság mára már kibontotta, megmagyarázta ${ }^{6}$.

Kötetünkben a nyílt tudomány különböző részeiről már részletesen írtunk. A közösségi tudomány a legfrissebb eleme a szerteágazó nyílt tudománynak, mindenképpen fontos szerepet játszik a tudomány társadalmasításában, az elefántcsont-toronyban lévő tudomány közelebb kerül az átlagemberekhez a nyílt hozzáféréseken és a szabad információkon keresztül. Azáltal, hogy az átlagember részt vállal egy tudományos programban, sok esetben felelősebb és tudatosabb állampolgár lesz. Biztosan igaz az az állítás is, hogy azoknak a tudósoknak, akik hosszú időt töltenek ilyen tevékenységgel, átalakul a beszédmódjuk, és - ez alapvető félelmük is - lassan egyszerűsödik a gondolkodásuk, és elveszítik újító erejüket. Igen, ez lehet valós veszély, ugyanakkor azt is számba kell venni, milyen eredményeket hoz(hat) a közösség tudománya a „magas” tudományok művelőinek. A számítógép és általában a digitális technológia használata is a gondolkodás egyszerűsödéséhez, végsősoron az újító erő elveszítéséhez is vezethet. Mégis, mindig számolunk az IT kutatást segítő erejével - ma még ezt érezzük erősebbnek, és nem a romboló hatásukat. Az arányokra, vagyis az arany középútra kell mindenkor figyelni, ahogy már az ókorban is felemelkedtek a figyelmeztető ujjak: via media aurea!

4 Citizen Science, Innovation in Open Science, Society and Policy, ed. Hecker, Susanne, Haklay, Muki, Bowser, Anne, Makuch, Zen, Vogel, Johannes, Bonn, Aletta, London, UCL Press, 2018, 580. http://www.oapen.org/ search?identifier=1001816 (utolsó megtekintés: 2021. 07. 03.)

5 Uo., 3. https://discovery.ucl.ac.uk/id/eprint/10058422/1/Citizen-Science.pdf (utolsó megtekintés: 2021. 07. 03.

6 Az Európai Bizottság oldala https://ec.europa.eu/digital-single-market/en/ citizen-science (utolsó megtekintés: 2021. 01. 16.) 
Európában 2014-ben alakult meg a European Citizen Science Association ${ }^{7}$, mely tömöríti a közösségi tudománnyal foglalkozó különböző szakembereket és intézményeket. Célja, hogy támogassa a közösségi tudománnyal kapcsolatos tapasztalatok és ötletek megosztását, terjessze a közösségi tudományos projektek eredményeit, közösséget építsen. Aggregátorként működik, összegyűjti az európai jó gyakorlatokat, a közösségi tudománnyal kapcsolatos irányelveket, útmutatókat, kiadványokat.

Az Egyesület kidolgozta a közösségi tudomány 10 alapelvét $^{8}$, mely nagyban hozzájárul a projektek megvalósításához, kutatócsoportok és jogalkotók megszólításához, az eredmények tudományos elismertségéhez.

1. KözÖSSÉGI TUDOMÁNYOS PROJEKTEK A TÁRSADALOM TAGJAIT AKTÍVAN VONJÁK BE A TUDOMÁNYOS MUNKÁBA, MELYEKBŐL ÚJ TUDÁS VAGY ÚJ ÉRTELMEZÉS SZÜLETIK.

Két nagyon fontos kritériumot tartalmaz az első pont, tulajdonképpen ez adja a közösségi tudományos projektek lényegét. A társadalom tagjai elkötelezett, lelkes önkéntesként, jelentkezhetnek egy közösségi tudományos programban való részvételre, munkájukkal hozzáadott értéket teremtenek, aktívan vesznek részt a folyamatban, melynek tudományos eredménye lesz. A projektek nagy részében az önkéntesek feladata a megfigyelés és az adatok pontos rögzítése, dokumentálása. Az önkéntesek által bevitt adattömeget és információáradatot az adott szakemberek elemzik, értelmezik, így tudnak akár új eredményeket is felmutatni. Egy példával szeretném megvilágítani az adatgyüjtés és dokumentálás lényegét, ami a kutatási folyamat alapját adja. Vegyük például a madárgyưrüzéseket. A madarak befogását, a régi gyűrű

7 A European Citizen Science Association honlapja https://ecsa.citizen-science. net/ (utolsó megtekintés: 2021. 07. 03.)

8 A European Citizen Science Association honlapján a 10 pont https://ecsa. citizen-science.net/wp-content/uploads/2021/05/ECSA_Ten_Principles_ of_CS_English.pdf (utolsó megtekintés: 2021. 01. 16.) 
levételét, az új gyưrű felhelyezését, a gyưrűn lévő adatok adatbázisban való rögzítését nyugodtan rábízhatjuk azokra az elszánt önkéntes fiatalokra vagy felnőttekre, akiket érdekel az ornitológia és szívesen foglalkoznak szabadidejükben a madarakkal. Az ornitológusok pedig a világméretű adatbázisban lévő adatokból dolgoznak. Megállapítják például, hogy egyik helyről a másikra mennyi idő alatt jutott el a befogott madár, az éghajlatváltozás milyen életmódváltozást okoz a madaraknál, vagy hogyan változtatják a vonulási útvonalukat, hogy csak pár szempontot soroljak fel. A példa is rögtön figyelmeztet: csak bizonyos fejlettségű társadalmakban működik ez. A polgároknak rá kell érniük erre a munkára, valóban kell lenni szabadidejüknek. Ők maguk döntsenek arról, hogy ezt a szabad időt erre fordítják. Atársadalmi felelősségtudatnak is jelen kell lennie, amelynek keretében a tudományos megfigyelés fontosságával tisztában vannak. Vagyis látniuk kell, milyen veszélyekkel jár, ha ők komolytalanul nem valós adatokat rögzítenek. A tudóst legfőképpen a saját munkájának fontosságába vetett hit vezényeli - a Föld forgása áll meg, ha egy madár költözési irányait nem ismerik, egy ma már nem beszélt nyelv morfémáit nem fejtik meg, vagy nem tudjuk, mit olvastak a 8. századi Skótföldön stb. -, az önkéntes polgárnak is kell rendelkeznie egy ilyen megszállottsággal. Erre a szintre azonban a társadalomnak el kell jutnia. Ahol a napi étel vagy víz szükségletének biztosítása a gond, ott nem valószínű, hogy felelősséggel fognak mondjuk zsiráf-nyilvántartást vezetni.

\section{A KÖZÖSSÉGi TUDOMÁNYOS PROJEKTEK EREDMÉNYE HITELES TUDOMÁNYOS EREDMÉNY.}

Sokan és sokszor megkérdőjelezik a közösségi tudományos projektek eredményeit, éppen ezért számos tanulmány ${ }^{9}{ }^{10}$ látott napvilágot arról,

9 Bonter, David N., Cooper, Caren B., Data validation in citizen science: a case study from Project FeederWatch, Frontiers in Ecology and the Environment, Vol. 10, issue 6. https://doi.org/10.1890/110273 (utolsó megtekintés: 2021. 07. 03.)

10 Wiggins, Andrea, Newman, Greg, Stevenson, Robert D., Crowston, Kevin, Mechanisms for Data Quality and Validation in Citizen Science, 2011 IEEE Seventh International Conference on e-Science Workshops, Stockholm, 2011, 14-19. https://doi.org/10.1109/eScienceW.2011.27 (utolsó megtekintés: 2021. 07. 03.) 
hogy milyen hitelesítési folyamaton esnek át a különböző képzettségű és tapasztalatú önkéntesek által rögzített adatok. Általánosságban elmondható, hogy nagy különbségekkel találkozhatunk projektenként. A közösség önkéntesei által szolgáltatott adatok minősége elsősorban a projekt előkészítésétől függ. Egy jól előkészített projektben a kutatók vagy a kutatók által felkészített moderátorok (ilyenek lehetnek például a könyvtárosok) érzékenyítik és betanítják az önkénteseket a pontos feladatra, hogy minél egyértelműbb legyen az elvárt minőség. Több esetben előfordul, hogy az önkénteseknek egy alkalmassági vizsgálaton kell átesni, bizonyos kompetenciákra, készségekre van szükség egy-egy feladathoz. Például növények, bogarak leírásánál a színtévesztés kizáró ok lehet, vagy szövegátírásnál az adott nyelv nem ismerete szintén alkalmatlanná teszi az illetőt. Minden közösségi projektben valamilyen szinten ellenőrzésre kerülnek a bevitt adatok, akár szúrópróba-szerűen, akár részletesen, ezeket minden esetben szakemberre bízzák, tehát az ellenőrzés beépített, a kérdés az arányokon van.

Általánosságban elmondható, hogy a jól előkészített projektek estében nagyon magas minőségen, elhanyagolható hibaaránnyal dolgoznak az érdeklődő - hála Istennek, sokszor megszállott - önkéntesek. Később részletesen kitérek a könyvtárak és könyvtárosok szerepére, de itt is aláhúznám, hogy a felkészítő tréningek, amiket sok esetben a könyvtárosok tartanak, a kulcsa a sikeres közösségi tudományos projekteknek.

\section{Mind a tudósoknak, Mind az ÖNKÉNTESEN RÉSZTVEVŐ ÁLLAMPOLGÁROKNAK KÖLCSÖNÖSEN ELŐNYÖS A KÖZÖSSÉGI TUDOMÁNYOS PROJEKTEKBEN VALÓ RÉSZVÉTEL.}

Az önkéntes munkával és az iskolai közösségi szolgálattal rendszeresen találkozunk, ezek alapján elmondhatjuk, hogy még a kelet-európai régiókban is kezd újra elterjedni ez a fajta közösségi vállalás, annak ellenére, hogy a szocialista időkben meghirdetett „társadalmi munka” nem hagyott túl sok pozitív hagyományt maga mögött. Az önkéntesek, akik sok esetben már nyugdíjasok, tehát a szabadidejükkel könnyebben 
gazdálkodnak, örömmel vállalnak feladatokat. Az MTA Könyvtár és Információs Központban jelenleg nyolc önkéntessel van szerződésünk. Őket kérdezve, elsősorban azért vállalnak sokszor nem intellektuális kihívást jelentő feladatot, mert szeretik hasznosnak érezni magukat, a szabadidejüket szeretnék olyan munkával eltölteni, aminek értelme van, szeretnének egy közösség részévé válni, és nem utolsósorban érdekli őket egy könyvtár tevékenysége. A közösségi tudományos projektek sikere az önkéntesek motivációján és eltökéltségén áll vagy bukik, éppen ezért érdemes erre figyelni, és a projektvezetőknek energiát fektetni ebbe. Az angliai Institution of Environmental Sciences ${ }^{11}$ leírása alapján a következő motivációk alapján vállalnak az önkéntesek feladatot: érdekli őket a téma, szeretnének valami újat tanulni, szeretnének valami újat felfedezni, szeretnének több időt tölteni a természetben, olyan emberekkel barátkozni, akiknek hasonló az érdeklődési körük, szeretnének önkénteskedni, szeretnének valamivel hozzájárulni a tudományhoz, úgy érzik, fontos segíteni. Összefoglalva, azok, akik önkéntesként bármilyen feladatot vállalnak, akár közösségi tudományos projektekben, akár jószolgálati tevékenységet, akár egyházi feladatot, úgy érzik, hogy valamit adnak a világnak, ezáltal ők is többek lesznek. (És valóban!)

Talán egyszerűbb volt megfogalmazni, hogy az önkénteseket mi motiválja, de a kutatók, a szakemberek vajon miért választják ezt a megoldást a kutatáshoz?

Elsősorban a nagy tömeg vonzza őket. A közösségi tudományos projektek nagy része természettudományos, országokon, akár kontinenseken átívelő programok (gondoljunk a gólyák vagy a vadludak, fecskék vonulási szokásainak vizsgálatára), képtelenség lenne mindenhova szakembert küldeni, hogy adatokat jegyezzenek fel. Az adott téma iránt érdeklődő és elkötelezett közönség által begyüjtött

11 KRAGH, Gitte, The motivation of volunteers in citizen science, Environmental Scientist, 2016. August, Vol. 25., No 2., 32-35. https://www.the-ies.org/sites/ default/files/journals/es_citizen_science_aug_16.pdf (utolsó megtekintés: 2021. 07. 03.) 
adatokból nagyobb merítést lehet egy-egy kutatás során végezni, a több adat sokkal jobban alátámaszthatja vagy cáfolhatja az elméleteket, tehát a közösség tagjaival tulajdonképpen a humánerőforrás-hiányt pótolják. $\mathrm{Az}$ önkéntes munkáért nem jár semmilyen anyagi honorárium (vagy nagyon ritkán és akkor is minimális összeg), tehát a kutatócsoport nemcsak humánerőforrást nyer, hanem a költségvetés jelentős részét megtakaríthatja és másra fordíthatja. Azért itt meg kell jegyezni, hogy egy jól működő közösségi tudományos projekt költségvetése viszonylag magas, mert a moderátorok és önkéntesek felkészítése költséges, ezen kívül nagyon sokat kell a marketing tevékenységbe fektetni, a motivációt fenntartani az önkéntesekben, ezután jön még csak az adatmentés és archiválás kérdése, ami szintén kiadásokkal jár, és a kutatók megfizetése, hogy legyen tudományos eredménye a projektnek. De visszakanyarodva a kérdésünkhöz, nem véletlen, hogy Európa-, sőt világszerte nagyon sok közösségi tudományos projekt működik. A „miért”-eknél meg kell említenünk egy egyáltalán nem elhanyagolható szempontot is, ez pedig az adott tudományos terület ismertsége. Kutatási projekteket nem szoktak az autópályák mellett óriás plakátokon hirdetni, általában a köz emberének nincs tudomása arról, hogy milyen kérdések foglalkoztatják a tudományos világot. Azáltal, hogy önkéntesek is bekapcsolódnak a munkába, egy új disszeminációs terület nyílik. Már a toborzás során sokan hallanak az adott kutatásról, azok pedig, akik részt vesznek egy-egy tudományos kutatásban, büszkén mesélnek ismerősieknek a „munkájukról”. Ezáltal egy teljesen új, megbízható reklámfelülethez jutnak a kutatócsoportok. A közösségi tudományt legtöbb esetben a természettudományos kutatások használják ki, ezáltal a részt vevő közösséget megfelelően érzékenyítik a klímaváltozásról, a zsiráfok csökkenő egyedszámáról, a madarak megváltozott költözési szokásairól stb. Ennek köszönhetően a közösségi tudományos projektek keretében zajló kutatások sokkal nagyobb ismertségre és elismertségre tesznek szert, így az adott szakmában folyó munkának hírértéke lesz.

A European Citizen Science Association nem vette fel a közösségi tudomány 10 alapelve közé a könyvtárakkal való kapcsolat fontosságát. Úgy vélem, hogy a 2015-ben kidolgozott alapelveket ma már 
mindenképpen ki lehetne egészíteni azzal, hogy Mind a tudósoknak, mind az önkéntesen résztvevő állampolgároknak, mind a könyvtáraknak kölcsönösen előnyös a közösségi tudományos projektekben való részvétel. 4. A KÖZÖSSÉGI TUDOMÁNYOS PROJEKTEKBEN AZ ÖNKÉNTESEK A
TUDOMÁNYOS MUNKA AKÁR TÖBB LÉPÉSÉBEN IS RÉSZT VEHETNEK.

A közösségi tudományos projektek felépítése minden esetben a kutatócsoporttól, a vezető kutatótól függ. Mint minden munkafolyamat, a közösségi tudományos projekt is csak akkor lesz sikeres, ha pontosan előre megtervezik, ha minden feladatnak megvan a gazdája. A szóban forgó projekteknek van olyan része (szervezés, oktatás, marketing, $\mathrm{PR}$, gazdasági, informatikai), mely nem a kutatási terület szakemberének a szakterülete, így akár ezeken a feladatokon is dolgozhat önkéntes. Kifejezetten előnyösnek tartom a marketing és a kommunikációs folyamatokba is bevonni a közösség tagjait, hiszen lelkesedésükkel, elhivatottságukkal újabb és újabb önkénteseket tudnak bevonni a kutatásba. Sokszor tapasztaltam saját munkám során is, hogy a „laikusok” kérdésfeltevései, új perspektívájuk sokszor segítik a munkát, tehát a társadalom tagjai akár kezdeményezői is lehetnek a vizsgálatnak. Ilyen projektek lehetnek például településfejlesztési kérdések vagy a közösségi közlekedés átalakítására, forgalomszabályozásra irányuló kezdeményezések.

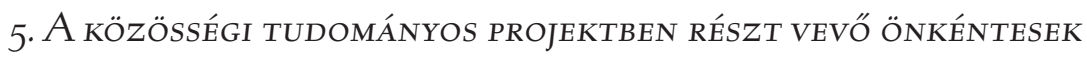
MINDIG KAPNAK VISSZAJELZÉST A PROJEKTRŐL ÉS A MUNKÁJUKRÓL.

Nemcsak a sikeres közösségi tudományos projektek alapja a résztvevőknek szóló visszajelzés, hanem egy jól működő szervezetben is elengedhetetlen az értékelés, minősítés, visszajelzés. Ahogy már beszéltünk róla, fontos a motiváció fenntartása az önkéntesek között, a visszajelzés pedig mindenképpen motivációs eszköz, hogy a résztvevők lássák a munkájuk eredményét, magukénak érezzék a projektet, ne csak a célokkal azonosuljanak, hanem az eredményekkel is. 


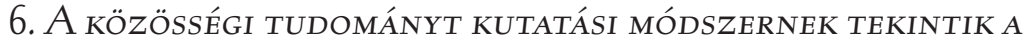
MAGA KORLÁTAIVAL ÉS KUTATÁSI ELFOGULTSÁGAIVAL, MELYEKET A KUTATÁSI FOLYAMAT SORÁN FIGYELEMBE KELL VENNI ÉS ELLENŐRZÉS ALATT KELL TARTANI.

A tudományos módszer alapján a kutatócsoport egy teóriából kiindulva hipotézist állít fel, melyet kvalitatív vagy kvantitatív vizsgálatokkal elemeznek, így a kutatás végén igazolják vagy cáfolják az eredeti állítást. A közösségi tudományos projektek nagy előnye az önkéntesek magas részvétele. Általában egy-egy projekthez nagyon sok önkéntes csatlakozik, ami rengeteg adatbevitelt, megfigyelést és dokumentált azonosítást jelent. Ez a tény magában hordozza a nagy számok elvét, miszerint minél több adatot dolgozunk fel, annál biztosabb megállapításokat tehetünk, így a kutatás elfogultsága is kevésbé jellemző. Sajnos, az is nagyon személyfüggo - és egyre kevéssé jellemző -, hogy a hipotézist nem igazoló adatgyüjtés után magát az elméletet vetik el. Könnyebben minősítik az adatgyűjtést szakmailag hiányosnak, és legyünk őszinték - ha ebben önkénteseket alkalmaztak, egyszerű útnak számít az előfeltevéstől való eltérést ennek számlájára írni.

\section{A közösségi tudományos projeKtek adatai ÉS metaAdatai NYILVÁNOSAK, ÉS AMIKOR CSAK LEHET, AZ EREDMÉNYEKET NYÍLT HOZZÁFÉRÉSSEL KELL PUBLIKÁLNI.}

A közösségi tudomány a nyílt tudomány mozgalom egyik pillére, és mint ilyen, nem kérdés az adatok nyílt hozzáférése és az eredmények, beszámolók, jelentések nyílt publikálása, visszakereshetősége. A nyílt tudomány egyre többet hangoztatott elve a rekonstruálhatóság. $\mathrm{Az}$ államilag támogatott kutatásoknak nemcsak az eredményeihez, publikációihoz kellene hozzáférniük az adófizetőknek, hanem ez azt is jelenti, hogy a nyílt adatok alapján legyen újra rekonstruálható a kutatás, az adatok hozzáférésével egy másik kutató, kutatócsoport is dolgozhasson. Bár nem a Citizen Science témához kapcsolódik közvetlenül, hanem az open data-hoz, de érdemes szemügyre venni a COVID-19, koronavírus-járvány kapcsán látottakat. Nagyon fontos, 
hogy a kutatási adatok nyíltan hozzáférhetőek legyenek a világ minden részén, ez alapján az európai kutatók, így a hazánkban kijelölt szegedi biológusok is hozzáférhettek a kínai orvosok által regisztrált esetekhez. Ugyan, ez egy nagyon szép elv, de, sajnos, soha nem fog teljesen megvalósulni, mert az érdekek és a pénz mindig közbeszól.

\section{A KÖZÖSSÉGi TUdOMÁNYOS PROJEKTEKBEN RÉSZT VEVŐ ÖNKÉNTESEKET KÖSZÖNETNYILVÁNÍTÁS ÉS ELISMERÉS ILLETI MEG A PROJEKT EREDMÉNYEINEK KÖZZÉTÉTELEKOR ÉS A PUBLIKÁCIÓKBAN.}

A közösségi tudományos projektekben soha nem fogják nevén nevezni a több ezer résztvevős önkéntest, de összességében alapvető elvárás, hogy a kutatás alapját biztosító tömeg mégis érezze a tudományos világ elismerését. A kisebb, helyi közösségekben létrejött projekteknél pedig a település is biztos büszke az önkénteseire, így nem is felejtik el név szerint megköszönni a közremúködésüket.

A köszönetnyilvánítás nemcsak az adott projekt szempontjából fontos, hanem a jövőre nézve is, hiszen ez is motivációs eszköz! Aki megbecsültnek, hasznosnak, eredményesnek érezte magát és munkáját egy adott közösségi tudományos projektben, az szívesen csatlakozik egy újabbhoz.
9. A KÖZÖSSÉGI TUDOMÁNYOS PROGRAMOKAT A TUDOMÁNYOS EREDMÉNYÜK ALAPJÁN, AZ ADATOK MINŐSÉGE, A RÉSZTVEVŐK TAPASZTALATAI ÉS A TÁGABB TÁRSADALMI ÉS SZAKMAPOLITIKAI HATÁSUK ALAPJÁN KELL ÉRTÉKELNI.

A European Citizen Science Association által kiadott 10 alapelv 9. pontja azt mondja ki, hogy mi alapján értékeljük a projekteket, de a fenti állításban megbújik egy nagyon fontos, ki nem mondott és le nem írt értékelési lehetőség, mégpedig az, hogy mi alapján ne értékeljük a közösségi tudományos projekteket: ez pedig a résztvevő 
önkéntesek száma. Bár már beszéltünk arról, hogy a nagy számok elve alapján valószínűsíthető, hogy ha minél többen vesznek részt egy megfigyelésben, átírásban, annál pontosabb lesz, de ez nem lehet az egyedüli értékelési alap. Tudunk olyan projektről, amelyben az önkéntesek egy személy kéziratos hagyatékát gépelik le, és így kerül be egy nagy adatbázisba a szöveg. Mivel a 19. század elején írt angol kéziratok olvasása mindenképpen szakértelmet, de legalábbis rutint igényel, ezért a programban hatékonyan résztvevők nem haladják meg az Egyesült Királyság-szerte a tíz főt, mégis, sikeres és tudományos mércével is igen fontos munka alapját teszik le. Gondoljunk bele: az MTA 2021-ben megvette Erdélyi János (1814-1868) és fia, Erdélyi Pál (1864-1936) irathagyatékát. Ez ma a legnagyobb 19. századi irodalmi hagyatékok egyike. Feldolgozása részben megtörtént, a benne őrzött szövegkorpusz átírása, tudományos feldolgozása és kiadása évtizedeket vesz majd igénybe. Egy ilyen tízfős csapat szervezése, felkészítése a munkára fél évet elvinne, de feltehető, hogy fél évtizedet megspórolnának a kívánt eredmény eléréséig. Közben lenne egy pozitív társadalmi hatása is a folyamatnak. Azonban sem a magyar irodalomtudományi élet, sem a társadalom nem érett még egy ilyen megoldásra.

\section{A KözösSÉgi tudományos projeKtek VezetőI figyelembe} VESZIK A SZERZŐI JOG JOGI ÉS ETIKAI KÉRDÉSEIT, MINT A SZELLEMI TULAJDON, AZ ADATMEGOSZTÁSI EGYEZMÉNYEK, A BIZALMI VAGYONKEZELÉS ÉS TEVÉKENYSÉGÜK KÖRNYEZETI HATÁSAIT.

Természetesen a nyílt hozzáférés nem jelenti azt, hogy ne kellene Európa-szerte figyelembe venni az Általános Adatvédelmi Irányelvet (GDPR), a szerzői jogot vagy bármely más hatályos rendelkezést, ami egy-egy kutatásnál felmerülhet. A teljes anonimitás biztosítása ugyanakkor a felelőtlenséget is nagyobb eséllyel engedné meg. Ha valaki közmunkát végez, ezt vállalja, ahogy vállalják is a résztvevők, azt ne anonim módon tegye. 


\section{KÖZÖSSÉGI TUDOMÁNYOS PROJEKTEK}

Az angolszász szakirodalom az 1900. évben kezdődött Karácsonyi Madárszámlálást (Christmas Bird Count ${ }^{12}$ ) tartja a legrégebbi dokumentált közösségi tudományos projektnek - persze, akkor még nem így hívták. 1900 karácsony napján (december 25.) hirdette meg egy észak-amerikai ornitológus, Frank M. Chapman a madárszámlálást, mivel meg volt győződve arról, hogy a madárpopuláció kihalóban volt a karácsonyi galamblövészet szokása miatt. A vadászatot szerette volna felváltani a számlálással, és már az első évben sikeres volt a kezdeményezése, 27 madárszámláló csatlakozott hozzá, és 25 különböző területről küldtek adatot, Torontóból, Ontario-ból, Pacific Grove-ból és Kaliforniából.

A Karácsonyi Madárszámlálás jó példa a közösség bevonására, azonban nem is gondolnánk, hogy hazánkban már 1881-ben közösségi tudományos projekt keretében szervezte meg Heller Ágost a zivatarészleléseket. A Természettudományi Közlöny (1881. június) 13. évfolyam 142. számában a Levélszekrény rovatban (p. 277.). ${ }^{13}$ Heller Ágost 13 pontban adta meg a megfigyelési módszereket, melyek nagyon részletes leírást és összehasonlítást tettek lehetővé. Két évvel később szintén a Természettudományi Közlöny ${ }^{14}$ hasábjain ismételte meg a felhívást, és egyben köszönetet mondott az adatküldő önkénteseknek, kiemelve név és foglalkozás, illetve település szerint a legteljesebb leírást küldőket. A zivatarokat, villámcsapásokat dokumentálók között volt tanító, lelkész, főgimnáziumi tanár és gyógyszerész is.

12 History of the Christmas Bird Counting https://www.audubon.org/ conservation/history-christmas-bird-count (utolsó megtekintés: 2021. 07. 04.)

13 Zivatarok statisztikája érdekében, Természettudományi Közlöny, 142(1881), 13. évf., 277. http://real-j.mtak.hu/6576/1/TermtudKozl_1881.pdf\#page=289 (utolsó megtekintés: 2021. 07. 04.)

14 Heller Ágost, Zivatarok statisztikája érdekében, Természettudományi Közlöny 166(1883), 15. évf., 285. http://real-j.mtak.hu/6578/1/TermtudKozl_1883. pdf\#page=293 (utolsó megtekintés: 2021. 07. 04.) 
Manapság az újdonság a nyílt tudományban rejlik, a nyílt adatokban és a nyílt hozzáférésben és persze a technikai háttérben, melynek segítségével az elemzések egyre összetettebbek és sokoldalúbbak lehetnek. A projektekbe rengeteg erőforrást fektetnek a szervezők, hiszen ki kell építeni egy informatikai hátteret, fel kell készíteni a projektben részt vevő önkénteseket, folyamatosan ellenőrizni kell az adatokat, és visszajelzést kell adni az önkénteseknek. A mai online világban tulajdonképpen állandóan talpon kell lenni, és állandóan fenn kell tartani az érdeklődést és a lelkesedést.

Számos jól bevált közösségi tudományos projektet sorolhatnánk fel, a Zooniverse.org kifejezetten azt a több mint egy millió fős nemzetközi önkéntes közösséget fogja össze, akik örömmel vállalnak feladatot egyegy kutatásban. Színes a kínálat, a csillagszámlálástól, a zsiráfok foltjai alapján való azonosítástól, pingvinszámlálásig nagyon sokféle projekt megtalálható.

A jó gyakorlatok között egy olyan angliai példát szeretnék kiemelni, amikor a tudományos könyvtár nemcsak szervezi a projektet, hanem a kutatást is a könyvtár vezeti. Ez a University College London egyetemi könyvtára által kezdeményezett és koordinált Transcribe Bentham ${ }^{15}$ projekt. A projekt több szempontból is érdekes számunkra, hiszen kifejezetten kulturális örökségünk megőrzésére irányul, illetve jó példája a könyvtárban és könyvtári gyűjteményen alapuló projekteknek. Jeremy Bentham (1748-1832) angol filozófus, bíró, az utilitarizmus atyja és egyben a London University (1826) alapítója (az egyetem később, 1836-ban vette fel a University College London nevet), kéziratos hagyatékát az egyetem könyvtárában őrzik. A University College London elkötelezett híve a nyílt tudománynak, az egyetem égisze alatt, szervezetileg pedig a könyvtárban hozták létre az Egyesült Királyság első Open Access (nyílt hozzáférésű) kiadóját is ${ }^{16}$, így aztán nem

15 University College London honlapja, Transcribe Bentham https://blogs.ucl.ac.uk/transcribe-bentham/ (utolsó megtekintés: 2021. 07. 04.)

16 University College London Press honlapja https://www.uclpress.co.uk/ (utolsó megtekintés: 2021. 07. 04.) 
meglepő, hogy elsőként vágott bele az egyetemi könyvtár egy könyvtári gyűjteményen alapuló közösségi tudományos projektbe. A Transcribe Bentham célja a könyvtárban található 60000 fólió Bentham-kéziratok eddig feldolgozatlan 12500 fólió feldolgozása, átírása és kiadása. Az önkéntesek feladata a szkennelt kéziratok átírása megadott szabályok alapján a projekt elektronikus felületén. A projektet 2010-ben hirdették meg, az elmúlt időszakban a 46535 szkennelt képnek a felét sikerült átírni. Időközben az önkéntesek munkája mellett kipróbálásra kerül egy új kézírást felismerő szoftver is, ami még egyáltalán nem helyettesíti az önkéntesek munkáját. A munkafolyamatot pontos tervezés előzte meg. Mi, akik könyvtárban dolgozunk, tisztában vagyunk a hatalmas értékes hagyatékok feldolgozatlanságával, hazánkban a 19. századi kéziratok nagy része kiadatlan maradt, és, sajnos, feldolgozatlan is. A technikai fejlesztéseknek köszönhetően sok munkafolyamatot lehet már mesterséges intelligenciával helyettesíteni, de számos területen még mindig nem tudjuk kikerülni az emberi agy produktivitását. A meghirdetett közösségi tudományos projekthez való csatlakozás regisztrációval és felkészülési idővel kezdődik. A regisztráció során az általános adatokon kívül a rövid kérdőív kitér arra is, hogy az átíró önkéntesnek van-e bármilyen paleográfiai tapasztalata vagy képzettsége. Az önkéntesek által készített gépiratokat minden esetben a könyvtár és egyetem szakemberei ellenőrzik. Az egyik leggyakrabban felvetődő kérdés, hogy milyen hatékonysággal dolgoznak az önkéntesek, nem több idő-e és energia a gépiratok ellenőrzése, összevetése az eredeti szöveggel. Minden kétséget eloszlató elemzés jelent meg 2018-ban ${ }^{17}$, mely a projekt időszakából nagyjából két évet alapul véve 2012. október 1. és 2014. június 27. közötti időszakot vizsgálva kimutatta, hogy az ellenőrzések során csupán a bevitt szavak 1\%-át kellett az ellenőrző szakembereknek módosítani. A projektre fordított energia megtérülése szokott még kérdés lenni. Pénzbe, időbe kerül létrehozni azt az

17 Causer, Tim, Grint, Kris, Sichani, Anna-Maria, Terras, Melissa, 'Making such bargain': Transcribe Bentham and the quality and cost-effectiveness of crowdsourced transcription, Digital Scholarship in the Humanities, Vol. 33, Issue 3, September 2018, 467-487. https://doi.org/10.1093/llc/fqx064 (utolsó megtekintés: 2021. 07. 04.) 
informatikai hátteret, mely alapot biztosít a szkennelt dokumentumok láthatóvá tételére és a gépiratok mentésére. Szükség van egy nagy kapacitású szerverre is, ahol a repozitóriumi anyagot archiválni lehet. Az önkéntesek felkészítése, a velük való kapcsolattartás, kérdéseikre való válaszadás szintén megkövetel egy háttérmunkát. A csapat részét képezik azok a szakemberek, akik az átírásokat ellenőrzik, és azok is, akik a kész részeket előkészítik kiadásra, szerkesztik a már begépelt részeket. Az informatika ma már számos más kutatási területet is segít, így nemcsak szövegbányászati eszközökkel elemzik a gépiratokat, a benne szereplő neveket, hanem a legújabb kézírás-felismerő szoftver használatával megállapítják, hogy „hányféle kéz” segítette Bentham munkáját.

Ahogy írtam is, a projekt 2010-ben kezdődött, de még mindig tart, és valószínűsíthető, hogy még jó pár évig van munkájuk azoknak az önkénteseknek, akik örömüket lelik Bentham kéziratainak feldolgozásában. A projektről beszámoló cikkek egyértelmű sikerként mutatják be a projektet annak ellenére, hogy igen elhúzódó, a projektvezetés már többször cserélődött ez idő alatt. Látni kell, hogy a siker és a részeredmények, illetve majd a végső kiadás nagyban függ az intézmény elköteleződésétől, a projekt szervezésétől, az önkéntesek korrekt tájékoztatásától, a folyamatos motivációtól. A közösségi tudományos projektek között nem szokványos az ilyen hosszú feladat, talán ez az egyetlen, amit nem biztos, hogy jó gyakorlatként át kellene venni a University College Londontól, azonban nagyon tanulságos a magyar könyvtárak, muzeális gyűjtemények számára. Nem kell messzire menni egy közgyüjteménynek sem a feldolgozatlan, akár ismeretlen anyagok tekintetében, sokszor egy-egy hagyatékról azon kívül, hogy van, nem tudunk semmit. Kulturális örökségünk részei. A közösségi tudományos projektek újabb lendületet adhatnak lappangó javaink felkutatásában és bemutatásában. Még becsülni is nehéz lenne, hogy pontosan hány kézirat-, fényképgyüjtemény van közgyüjteményeinkben. 


\section{A KÖZÖSSÉGI TUDOMÁNY SZEREPLŐI}

A кutatók

A közösségi tudomány definiálásával egyértelművé tettük, hogy legalább két „szereplője” van a projekteknek: a kutató, tudós, szakember és az érdeklődő önkéntes. A találkozás azonban nem mindig egyszerű, a felek egymásra találásában több szereplő is részt vehet. A Zooniverse internetes felület megalkotásával éppen a kommunikációt és az egymásra találást kívánják segíteni. A Zooniverse weboldalt a Citizen Science Alliance (Közösségi Tudomány Szövetség) gondozza, főként tudományos munkával foglalkozó szakemberek, szoftverfejlesztők és oktatók a világ különböző egyetemeiről vesznek részt a munkában. Két központja is van a Szövetségnek, az Oxfordi Egyetem NagyBritanniában és az Adler Planetárium az Amerikai Egyesült Államokban. A Zooniverse nemzetközi platform, mindenképpen érdekes számba venni a felsorolt projekteket; jól látható, hogy egy nemzetközi internetes portál mennyire megmozgatja az embereket, aktivizálja az érdeklődőket. Véleményem szerint, azonban hazánkban mégsem fog elterjedni a Zonniverse használata, már csak a nyelvi akadályok miatt sem, a projektek angol nyelvtudást igényelnek. A másik fó akadályt abban látom, hogy nincs személyes kapcsolat az önkéntesek és a szakemberek között, de még az önkéntesek és az aggregátor, moderátor szerepét betöltő platform között sem. Éppen ezért gondolom úgy, hogy a közgyüjtemények, így a könyvtárak, tökéletesen be tudják tölteni a harmadik fél szerepét. A könyvtárak rengeteg hozzáadott értéket tudnak egy-egy projektbe vinni, melyre később bővebben is szeretnék kitérni.

A közösségi tudományos projektek szereplőinél inkább azt vizsgáljuk meg, melyik félnek miért éri meg részt venni, milyen „haszonnal” jár egy-egy tudományos projekt.

A Nyugat-Európában, az Egyesült Államokban gyorsan terjedő kutatási módszertantól hazánkban a természettudósok már egyre kevésbé tartanak, a bölcsészek azonban szkeptikusak az eredményeket illetően. 
A már megvalósult projektekből jól látszik, hogy a sok önkéntest megszólító programok olyan lehetőségeket nyújtanak a szakemberek számára, amelyek máskülönben, humánerőforrás hiányában soha nem valósulhatnának meg. Például a Magyarország növényzetét vagy állatvilágát feltérképező (MÉTA ${ }^{18}$, Vadonleső ${ }^{19}$ ) programok lehetővé teszik az önkéntesek online adatszolgáltatását, adott fajok helyzetmegjelölését. Az így összegyüjtött, országos lefedettséget biztosító adatokból a kutatók folyamatosan tudják frissíteni az aktuális élőhely-adatbázist és élőhelytérképet. A szakmai eredmények mellett célkitűzés a közösségek felkarolása, a különböző társadalmi csoportok összefogásának ösztönzése, az adott szakterületre vonatkozó (pl. ökológia, botanikai, csillagászati, történelmi stb.) ismeretek fejlesztése és a szemlélet formálása. A szakemberek a közösségi tudományos projektek kapcsán hiteles, gyorsan terjedő disszeminációs csatornához is hozzájutnak. Nem lebecsülendő, hogy a fiatalabb korosztály megszólításán keresztül, akár az utánpótlás biztosítására is van lehetőség. Tulajdonképpen az önkéntesek „ingyen” munkaerőt jelentenek a szakembereknek, azonban ez a megfogalmazás a folyamatok teljes leegyszerűsítése, hiszen a szakemberek minden esetben nagyon sok munkaórát tesznek bele az önkéntesek felkészítésébe, tájékoztatásába és a munkát követő „szabadidős” programokba.

\section{Az ÖNKÉNTESEK}

A European Citizen Science Association által összeállított alapvetéseknél már volt szó arról, hogy miért előnyös egy programhoz való csatlakozás az önkénteseknek. Fontosnak tartom hangsúlyozni, hogy a közösséghez való tartozás a 21 . század emberének fontos lételeme, az a tudat, hogy tevékenységünkkel, önkéntes munkánkkal hasznos dolgot, maradandót hozunk létre, szintén nem elhanyagolható. Ezen kívül pedig a résztvevők még élvezik is a feladatokat, ami saját önbecsülésüket is támogatja.

18 MÉTA program, Magyarország növényzeti öröksége https://www.novenyzetiterkep.hu/ (utolsó megtekintés: 2021. 07. 04.)

19 Vadonleső: önkéntesekkel a természetért https://vadonleso.hu/ (utolsó megtekintés: 2021. 07. 04.) 


\section{A KÖNYVTÁRAK}

A közösségi tudományos projekteknek nem alapvető, de hasznos résztvevője a könyvtár. Sok közösségi tudományos projekt elérhető a világhálón működő aggregátor felületeken, amelyek több ezer projektet kínálnak az önkénteskedő embereknek. A Zooniverse ${ }^{20}$ honlap leírása szerint egymillió ember kapcsolódik be a felkínált világméretű projektekbe. A több országon átívelő, akár különböző kontinenseket érintő projektek nagyobb költségvetéssel és nagyobb merítéssel dolgoznak. Azonban nagyon sok helyi, egy-egy kisebb közösséget, települést, egyetemi campuson élőket megmozgató közösségi tudományos projekt létezik világszerte, ahol a közösségi tudományos projekt résztvevői, azaz a kutató, az adott terület szakembere és az önkéntesen csatlakozó érdeklődő mellett megjelenik a könyvtár is, sok esetben a könyvtárak a projekt csomópontjai (hub), mozgatói. A könyvtár moderátorként kapcsolatot jelent a kutatócsoport, a tudományos világ és a projektben résztvevő emberek között. A könyvtárak általában egy-egy település, közösség középpontjában helyezkednek el, a látogatóközönségük nagyon széles skálán mozog, a gyerekektől a szülőkön keresztül a nyugdíjas korú emberekig, az egyetemeken pedig egyszerre használják az egyetemisták és az oktatók, kutatók, tehát az adott közösség minden tagja megfordul a könyvtárban. Ezen kívül a könyvtárhasználókról általánosságban elmondható, hogy érdeklődőek, nyitottak az újra, különböző szakterületüknek és különböző koruknak köszönhetően különböző módon látják a feladatot. A könyvtár, és leginkább a szakkönyvtárak, egyetemi könyvtárak, informatikai infrastruktúrája magas szinten áll, még Magyarországon is a legtöbb egyetemi és szakkönyvtár repozitóriumot működtet, már egyre több intézmény készen áll adatrepozitórium működtetésére is. Amiben a könyvtárak a legjobbak (sajnos, sok esetben a legnagyobb gyengesége is ez sok könyvtárnak): a jól képzett humánerőforrás, tehát maga a könyvtáros. És ha már az infrastruktúrát említettük, nem szabad megfeledkeznünk magáról a helyről. A könyvtárakat ma már csomópontként, találkozóhelyként (hub) emlegetjük, a harmadik hely, szocializációs színtér. A közösségi tudományos projektek

20 Zooniverse https://www.zooniverse.org/ (utolsó megtekintés: 2021. 02. 23.) 
szempontjából egy „semleges” terület, ahol otthonosan mozoghat az átlagember is és a kutató is. Hiteles hely, bár sokat emlegetjük ezt a kifejezést, de talán mégsem eleget. Igen, a könyvtárak megbízhatóak, a könyvtárban található információk és információforrások megbízhatóak, és a könyvtárosok szintén megbízhatóak. A könyvtárban dedikált helyet lehet biztosítani a közösségi tudományos projektekkel kapcsolatos tájékoztató anyagoknak, szórólapoknak (ahogy sok más terület számára is). Még akkor is állíthat össze a könyvtár egy tájékoztató leporellót, ha más módon nem is vesz részt a közösségi tudományban. Felhívhatja a figyelmet az aggregátor honlapokra, helyi közösségi tudományos projektekre, egy-egy projektben való részvétel jelentőségére, tapasztalatszerzésre. A könyvtáraknak (minden típusnak) alapfeladata az információáramlás támogatása, így jól megférnek egymás mellett az EU prospektusok, a katalógushasználati tájékoztatók vagy a könyvtár soron következő kulturális programját bemutató plakátok. Azonban az alapvető információk mellett a könyvtárnak szerepe van abban is, hogy a helyi, adott közösségben zajló közösségi tudományos projekteket támogassa. Ebben az esetben a „közösségi ponton” már konkrét információval tudják ellátni az érdeklődőket. A megvalósult európai közösségi tudományos projektek azt mutatják, hogy a könyvtárosnak kulcsszerep jut egy-egy projektben. Mindenképpen építhetünk a könyvtárosok kommunikációs készségeire és gyakorlatukra - megfelelő felkészítés után (képzők képzése) - a könyvtárosok lesznek azok, akik felkészítik, betanítják az önkénteseket és tájékoztatják a résztvevőket a közösségi tudományos projektek menetéről, lehetőségeiről, a csatlakozás tudnivalóiról, és ugyancsak a könyvtárosok azok, akik kapcsolatot tartanak a tudományos projekt vezetőjével is, így valóban a híd szerepét töltik be.

Az európai tapasztalatok azt mutatják, hogy a legtöbb közösségi tudományos projekt egy-egy egyetemről indul, így az egyetemi könyvtárak kézenfekvő segítséget jelentenek a projekt sikeres lebonyolításához. Ma már hazánkban sem elkülönülten dolgoznak a könyvtárosok, hanem az egyetemi tanszékekkel együttműködve, 
úgynevezett szakreferensekkel. ${ }^{21}$ A szakreferensi szolgálat kifejezetten jó hatással van a könyvtárhasználati statisztikákra is, hiszen a kölcsönös bizalom következtében sokkal többen fordulnak a könyvtárhoz és a könyvtároshoz. A könyvtárosok elfogadottsága, ha úgy tetszik, a hierarchia mind a két végéről biztosított, oktatók, kutatók is és a hallgatók is szívesen és könnyen fordulnak a könyvtárosokhoz. Ez az a bizalmi viszony, amelyre a közösségi tudományos projektek építenek a könyvtárak bevonásával.

A közösségi tudományos projektek zöme természettudományos jellegü, megfigyeléseken és adatrögzítésen alapulnak. Az adatok pontos rögzítése és biztonságos tárolása minden projektnél elengedhetetlen. A könyvtárak minősített adatrepozitóriumai megfelelnek a kutatási módszertan elvárásainak, a könyvtárakban dolgozó adatkurátorok (data curators) pedig szakszerűen kezelik az adatokat.

Eddig csak azokról a közösségi tudományos projektekről beszéltünk, amelyekben a könyvtár moderátorként, összekötőként áll az önkéntesek és a kutatócsoport között.

Mindenképpen fontos azonban megemlíteni, hogy a könyvtár gyüjteménye egy-egy kutatás alapja, helyszíne is lehet. Írott kulturális örökségünk zömmel könyvtárakban lelhető fel, olyan értékek rejtőznek sokszor intézményeinkben, amiről csak sejtésünk van. Az egyik legszemléletesebb példát már említettük a közösségi tudományos projekteknél, a University College London Citizen Science projektje a Transcribe Bentham ${ }^{22}$, mely az egyetemi könyvtár gyüjteményében található Jeremy Bentham-kéziratok átírását tűzte ki célul. A Benthamprojekt egy európai konzorcium részeként elnyerte az Európai Bizottság

21 Meskó Eszter, Egy könyvtár - tizenkét kar: az SZTE Egyetemi Könyutár szakreferensi rendszere, TMT, 57. évf., 4(2010). http://tmt-archive.omikk.bme.hu/show_news. html@id=5308\&issue_id=514.html (utolsó megtekintés: 2021. 07. 04.)

22 Project Update - Transcribe Bentham, woman and citizen science (23 March 2018) https://blogs.ucl.ac.uk/transcribe-bentham/2018/03/23/project-updatewomen-and-citizen-science/ (utolsó megtekintés: 2021. 07. 04.) 
Horizon Impact Award 202023 díját is, lappangó kulturális örökségünk hozzáférése kapcsán tett erőfeszítéseiért.

A londoni példa jól mutatja, hogy a kulturális örökségünket őrző gyűjteményeknek nem szabad megijedniük a lehetőségtől. A siker titka egyértelműen a jól megtervezett és felépített projekt, mely illeszkedik az intézmény hosszútávú stratégiájába. Úgy gondolom, fontos megjegyezni, hogy a közösségi tudományos projektek nem ingyenesek, nem nulla forintos költségvetésből megvalósítandók. Rengeteg energiabefektetéssel jár, mind a kutatócsoportnak, mind az üzemeltetési feladatokat ellátó kollégáknak.

A könyvtár - ha nem is hiteleshely (locus credibilis, mert akkor gazdag lehetne) - hiteles hely ${ }^{24}$. Egyre többet beszélünk a könyvtárról, mint harmadik helyről, a könyvtár közösségben betöltött szerepéről, de nem szabad megfeledkeznünk arról a tényről, hogy a könyvtár az a hely, ahol az információáradatban elvesző állampolgár segítségre találhat. A European Citizen Science Association által megfogalmazott alapelveknél is utaltam már a könyvtárak szerepére. A könyvtár tájékoztató tevékenysége nagyban hozzájárulhat egy-egy helyi közösségi tudományos projekt sikeréhez, elsődlegesen hiteles információkkal.

A könyvtárakban, világszerte, különböző tájékoztató pontokat állítanak fel, például az EU információs pontok. A közösség tagjai tudják, hogy az itt elérhető információk megbízhatóak. Éppen ezért többfajta kiadványt, szórólapot kell elhelyezni a „Közösségi tudományos ponton”, elsősorban arról, hogy mi a közösségi tudomány, hogyan zajlik egyegy projekt, hogyan lehet csatlakozni, milyen eredmények várhatóak, miért éri meg bárkinek is önkéntes munkát vállalni egy programban, és ha a településen vagy az adott közösségben (egyetemen) már elérhető

23 Consortium including Bentham Project receives European Commission's Horizon Impact Award for 2020 https://www.ucl.ac.uk/laws/news/2020/ sep/consortium-including-bentham-project-receives-european-commissionshorizon-impact (utolsó megtekintés:2021. 07. 04.)

24 Kokas Károly, Nagy Gyula, Molnár Sándor, A könyvtárak jövőjérōl - Reflexiók egy elózetes kutatási jelentés kapcsán, TMT, 2(2017), 64-82. 
közösségi tudományos projekt, akkor erről mindenképpen érdemes tájékoztatni az érdeklődőket. Ezek a kiadványok a figyelemfelkeltés és az érzékenyítés első fázisai. ${ }^{25}$

A könyvtár híd a kutatócsoport és az önkéntesek között, és a hídfőkön ott állnak a könyvtárosok. A szórólapokat kézbe vevők, érdeklődők kérdezni fogják a könyvtárost, neki pedig felkészülten kell válaszolnia. Tehát a könyvtárosok felkészítése és megfelelő minőségű és mennyiségű információval való ellátása a kutatócsoport munkáját segíti. Az általános információnyújtáson túl a helyi projektekhez kapcsolódóan az önkéntesek felkészítését, csoportos tájékoztatását is a könyvtárosokra lehet bízni. A könyvtárosok kommunikációs készségei és képességei már kipróbáltak, a felhasználóképzések terén már bizonyítottak, csoportos foglalkozások megszervezésében és megtartásában is számos eredményt tudnak felmutatni, nem is beszélve a napi kapcsolattartással járó helyzetekről. A könyvtáros egyben kapcsolattartó a projektért felelős kutatócsoport és az önkéntesek között, a kutatócsoport munkáját nagyban megkönnyíti, ha a könyvtárra és a könyvtárosokra támaszkodhat, hiszen nem kell kiépítenie a projekthez tartozó kommunikációs csatornát, felhasználhatja egy jól működő szervezet előnyeit.

A könyvtári szervezet másik előnye az infrastruktúra. A hely, a „harmadik hely”, a közösség számára az otthon és a munkahely mellett a kikapcsolódás helye is, csomópont, találkozási pont (hub). Az újonnan épülő könyvtáraknál megfigyelhető az az alapvető igény, hogy a társadalom, a közösség minden tagjának biztosítsák a megfelelő helyet, így vannak az elmélyült munkára, olvasásra, tanulásra kialakított részlegek, a csoportos foglalkozásokhoz használható előadók és a kiscsoportos közös munkához használható helyiségek, ezen kívül pedig a közösségi terek. A program során a könyvtár adhat otthont a kutatásban résztvevő helyi önkénteseknek a tájékoztatók, felkészítő programok megtartására, de a könyvtár lehet a színtere az eredményeket bemutató sajtótájékoztatónak vagy kiállításnak is. Kihasználva a könyvtárak és

25 Lásd melléklet Közösségi tudomány „szórólap”. 
könyvtárosok előnyeit, képességeit, érdemes a könyvtárosokra bízni az önkéntesek felkészítését. A projektben résztvevő szakemberekről nagy terhet vehetnek le a könyvtárosok, és persze rengeteg időt takaríthatnak meg azzal, ha a szakemberek a könyvtárosokat készítik fel, amolyan képzők képzése tréninggel, hogy később a könyvtárosok tartsák meg időről időre a projekthez csatlakozó önkéntesek felkészítését. A tudományos projekt témájától és területétől függően más és más elvárás van az önkéntesek felé, a pontos munkavégzés menetét, mint például a méréseket, adatbevitelt, szoftverhasználatot a könyvtárosok taníthatják meg az önkénteseknek.

A könyvtár információtechnológiai infrastruktúráját is számos területen tudja hasznosítani a helyi közösségi tudományos projekt. Az európai egyetemi könyvtárak tapasztalatai szerint az egyetemi könyvtár által fenntartott és működtetett repozitóriumok és adatrepozitóriumok nem csak archiválásra használhatók, hanem biztosítják az adatokhoz való nyílt hozzáférést is. Ehhez kapcsolódnak azok a szakmai kompetenciák, amelyekkel a könyvtárosok nemcsak gyüjtik, hanem karban is tartják a repozitóriumi dokumentumokat, hogy megtalálható, visszakereshető és újra hasznosítható legyen.

Egy közösségi tudományos projekt számára a könyvtár még egy hatalmas potenciális erővel bír, ez pedig a megszólítható önkéntesek nagy száma.

Feltehetjük a kérdést, de vajon miért éri meg a könyvtáraknak láthatóan sok energiát fektetni egy közösségi tudományos projektbe?

A különböző könyvtártípusok (közkönyvtár, egyetemi vagy szakkönyvtár) alapfeladata az információhoz való hozzáférés biztosítása. Ezen túl a közkönyvtárak szerepe az adott településen a magyar könyvtári rendszerben szerencsére igen számottevő, a kistelepülések feladatellátásához külön költségvetést rendel az állam (39/2013. (V. 31.) EMMI rendelet a Könyvtárellátási Szolgáltató Rendszer múködéséről), de a helyi értékek felkutatásában, megőrzésében és közzétételében a Hungarikum törvény (2012. XXX. törvény a magyar nemzeti értékekről 
és a hungarikumokról) is a településeket támogatja a helyi értéktárak létrehozásában. Az egyetemi szakkönyvtárak további alapfeladata a kutatás támogatása. A kutatástámogatás formája, eszköze változik, ehhez pedig a könyvtárak alkalmazkodnak. Meglévő szolgáltatásinkat nem sokkal kell kiegészíteni ahhoz, hogy sikeres közösségi tudományos projektekben vegyünk részt. A közösségi tudomány (Cítizen Science) a nyílt tudomány (Open Science) egyik pillére. A hazai egyetemi könyvtárak és szakkönyvtárak rengeteget tesznek azért, hogy a magyar tudományos kibocsátás láthatóbb és elérhetőbb legyen a világ minden részéről, számos jó gyakorlat hozzáférhető. A közösségi tudományos projektekkel éppen azt a célt tudjuk szolgálni, ami a nyílt tudomány célja, hogy a más szakterületen dolgozó laikusoknak is átláthatóbb, érthetőbb és kézzel foghatóbb legyen egy-egy kutatási téma. A közösség bevonásával ezt a célt tudjuk erősíteni. Ezen kívül pedig egy közösségi tudományos projekt felér egy remek marketing eszközzel, hiszen újabb fórumot biztosítunk a szolgáltatásaink népszerűsítésének, alkalmunk nyílik mind a kutatói társadalom, mind az érdeklődő laikusok számára megmutatni, hogy hatalmas lehetőségek rejtőznek falaink között.

A közgyüjtemények számára a marketing kulcskérdés. Vannak ezen a területen sikeresebb és kevésbé sikeres intézmények. Egyértelmü segítség a központilag indított tudománynépszerűsítő tematikus napok, ilyen hazánkban a Múzeumok éjszakája vagy a Kutatók éjszakája, melyek lehetőséget adnak a kisebb költségvetéssel rendelkező intézményeknek is a megmutatkozásra, kihasználva a központi promóció lehetőségét. Könyvtári területen az Informatikai és Könyvtári Szövetség koordinálása mellett az Országos Könyvtári Napok ${ }^{26}$ nyújt hasonló megjelenési lehetőséget a hazai könyvtáraknak. Az Amerikai Egyesült Államokban működő Citizen Science Association civil szervezet évről évre meghirdeti a Közösségi Tudomány Hónapját ${ }^{27}$, minden év áprilisában. Az Egyesület központi logóval, marketing

26 Informatikai és Könyvtári Szövetség honlapja, Könyvtári napok http://iksz.org. hu/hir/orszagos-konyvtari-napok-2 (utolsó megtekintés: 2021. 07. 04.)

27 Citizen Science Association https://www.citizenscience.org/events/citizenscience-month/ (utolsó megtekintés: 2021. 03. 13.) 
anyagokkal segíti a résztvevő intézményeket, közös felhívásokkal igyekeznek népszerűsíteni a tudományos projekteket, munkákat. A segítséget igénybe vevő intézmények kész forgatókönyvet kapnak, pontos időbeosztással, mikor érdemes meghirdetni az eseményeket, milyen felületeken mutassák be a könyvtár közösségi tudományos munkáját, a közösségi tudományos projekt kutatóinak a tevékenységét, a már elért eredményeket. Biztosítják a médiumokban való megjelenést, ezzel segítve a közös célt, minél nagyobb igényt kelteni egy-egy projektben való részvételre a társadalom különböző rétegeiben. $\mathrm{Az}$ európai szervezet, a European Citizen Science Association egyelőre még nem indított hasonló kezdeményezést, Európában ezen a téren nem mutatkozik akkora érdeklődés, mint Amerikában. Ugyanakkor az Európai Kutatók Éjszakája az Európai Unió tudományos stratégiájában kulcsszerepet játszó Horizon 2020 kutatási és innovációs keretprogram ${ }^{28}$ alapján valósult meg idáig minden év november utolsó hétvégéjén, bizonyosan folytatódik mind a kutatástámogatás, mind az ismeretterjesztés ezen a téren. A Magyar Tudomány Ünnepét ${ }^{29} 2003$ óta ünneplia Magyar Tudományos Akadémia, amely manapság már nemcsak november 3-ra redukálódik, hanem évek óta már egész novemberben ismeretterjesztő előadások, konferenciák kerülnek megrendezésre az ország nagyvárosaiban, egyetemi központokban a Tudomány Ünnepe kapcsán. Tulajdonképpen a már meglévő állandó eseményekhez lehetne kötni Európában és Magyarországon is a közösségi tudományra felhívó nap, hónap eseményeit. Miért ne lehetne november első hétvégéje a Közösségi Tudomány „Éjszakája”, így egyszerre kapcsolódhatna a Tudomány Ünnepe novemberi eseménysorozatához és a november végi Kutatók Éjszakájához? Az elmúlt évek tapasztalatai azt mutatják, hogy a központilag meghirdetett, központi népszerüsítéssel segített események mindig nagyon látogatottak, jó lehetőség az ismeretterjesztésre és az önkéntesek toborzására.

28 Horizon 2020 rövid bemutatása https://ec.europa.eu/programmes/ horizon2020/sites/horizon2020/files/H2020_HU_KI0213413HUN.pdf (utolsó megtekintés: 2021. 07. 04.)

29 A Magyar Tudomány Ünnepe https://hu.wikipedia.org/wiki/A_magyar_ tudom\%C3\%Alny_\%C3\%BCnnepe (utolsó megtekintés: 2021. 07. 04.) https://mta.hu/tudomanyunnep2020/(utolsó megtekintés: 2021. 03. 13.) 


\section{A KÖZÖSSÉGI TUDOMÁNYOS PROJEKTEK FELÉPÍTÉSE}

Mint minden projekt, a közösségi tudományos projektek is akkor lesznek sikeresek és eredményesek, ha kellőképpen előkészítik, a munkafolyamatokat meghatározzák, a projektben résztvevők pontosan tudják, hogy kinek mi a feladata. A közösségi tudományos projektek meghatározásánál már beszéltünk arról, hogy akkor lehet szó közösségi tudományos projektről, ha a kutatási szakterületen jártas szakember vezeti a projektet, illetve a munkafolyamat különböző fázisaiban, ilyen az önkéntesek munkájának ellenőrzése, szakemberek is részt vesznek. A közösségi tudományos projektek önkéntesei lehetnek a téma iránt érdeklődő egyének vagy a közösség különböző, már összeszokott csoportjai, például iskolai csoport, helyi civil szervezet tagjai. Sok esetben a könyvtárak a két csoport, a szakemberek és az önkéntesek közötti híd, összekötő szerepét töltik be.

Azokban az országokban, ahol a közösségi tudományos projektek bevált módszerként élnek, nemcsak civil szervezetek vállalják fel a tevékenységet, hanem akár kormányzati, állami támogatást is kapnak. Jó példa erre Ausztria; a Zentrum für Citizen Science ${ }^{30}$, mely az Oktatási, Tudományos és Kutatási Minisztérium fenntartása alá tartozik. Nemcsak népszerűsíti a közösségi tudományos projekteket, hanem pénzügyileg is támogatja a különböző közösségi tudományos projektek megvalósulását, és aggregátorként közvetíti az aktuális projekteket. Ausztriában az Österreich forscht ${ }^{31}$ országos szervezetként fogja össze a közösségi tudománnyal foglalkozókat, célja, hogy a közösségi tudományos projektek módszertanát és minőségét fejlesszék, ismertté és elismertebbé tegyék a közösségi tudományos tevékenységet, ezért évenkénti konferenciát is szerveznek.

30 Zentrum für Citizen Science honlapja https://zentrumfuercitizenscience.at/ (utolsó megtekintés: 2021. 07. 04.)

31 Österreich forscht honlap https://www.citizen-science.at/ (utolsó megtekintés: 2021. 07. 04.) 
Az osztrák példa jól mutatja, hogy állami projektekkel, támogatással, sokkal hatékonyabban lehet a kutatókat is érdekeltté tenni, az önkénteseket pedig motiválni. Az Open Science (nyílt tudomány) és ezen belül a közösségi tudomány is mozgalom formájában indult, azonban a tudományos világ nagyon is központosított, és ezzel együtt jár a finanszírozottsága is, akár államilag, akár magántőkével.

Fontos kiemelni, hogy a közösségi tudományos projekteknek is költségvetéssel kell rendelkezniük, befektetés nélkül nem lehet értéket teremteni. A nyílt tudomány és a nyílt hozzáférés kapcsán sokan úgy vélik, hogy „ingyen” van a tudomány, a publikáció, a tudományos eredmény. Úgy vélem, ez a „városi legenda” a tudományos körökben már régen megdőlt. A projektben önkéntesként dolgozók ugyan nem kapnak munkabért, de mint minden munkának, van anyagköltsége, eszközigénye, és nem szabad azt sem elfelejteni, hogy a szakemberek, a kutatók, akik a projektet vezetik, a munkájukat végzik. A Közösségi Régészeti Egyesület is az ásatáshoz szükséges eszközöket biztosítja az önkénteseknek. Ha az ásatás egy forró nyári napon van, akkor sátorról, árnyékról, pihenőhelyről és vízről is gondoskodik a terepen dolgozók számára.

Közösségi tudományos projektek kezdeményezője lehet maga a kutató, kutatócsoport, egy közösség intézményesült képviselete (önkormányzat), civil szféra képviselője (helytörténeti, helyismereti egyesület), helyi közgyűjtemény, a könyvtár, múzeum vagy levéltár és természetesen akár egyéni kezdeményezés is lehet a projekt alapja.

A projekt kezdeményezőjének első lépése a pontos célmeghatározás: mi a vizsgálandó terület, mire vonatkozik a kutatás, milyen előfeltételezésekkel rendelkeznek a kutatók, kik vesznek részt a kutatásban, a hivatásos szakemberekre vonatkozóan is pontos adatokra van szükség. A kutatási program leírásában ki kell emelni az önkéntesek feladatát, mit várunk el az önkéntesektől, van-e feltétele a programhoz való csatlakozásnak. A projekttől függően szükség lehet valamilyen előképzettségre, például adatbevitel esetében számítógépes felhasználói ismeretekkel kell rendelkezniük a jelentkezőknek. 
A tervezés időszakában számba kell venni a projekt eszközigényét is. A szakembereknek és az önkénteseknek is különböző eszközökkel kell dolgozniuk, gondolhatunk ásóra, ecsetre, papírzacskóra, de a legegyszerűbb esetben is jegyzetfüzetre és íróeszközre szinte minden projektnél szükség van. Az európai és amerikai természettudományos közösségi tudományos projektek sok esetben egy „csomagot” adnak át minden önkéntesnek. Gondoljunk például az időjárás-megfigyelésekre, nemcsak jegyzetfüzetet kapnak az önkéntesek, hanem egy előre elkészített kérdéssort kell rendszeresen megválaszolniuk, pont úgy, ahogy 1881-ben Heller Ágost is kitalálta a viharjelzések menetét, ezáltal az adatok összehasonlíthatók lesznek. Ezen kívül a csomag tartalmazhat még különböző mérőeszközöket, például a csapadékméréshez szabványos edényt vagy hőmérőket.

A tervezés időszaka semmiképpen nem hagyható ki, a jól végiggondolt munkamenet segít meghatározni a költségvetést is, amely szintén sarkalatos pontja a sikeres közösségi tudományos projektnek. Miután tudjuk a felmerülő költségeket, meg kell találnunk a forrást is. Nagyon sok finanszírozási forma ismert. Amikor egy kutatóintézettől indul a projekt, akkor az intézmény szokta finanszírozni, és az intézmény biztosítja a megfelelő számú szakember részvételét, munkaidejét és fizetését, az intézmény biztosítja az eszközöket és a projekt eredményeinek közzétételét is. A helyi értékek és érdekek mentén kialakuló közösségi tudományos projekteket általában a helyi önkormányzat vagy egy helyi civil szervezet támogatja anyagilag, de arra is van példa, hogy magánemberek finanszíroznak egy projektet, vagy több érdekelt közösen fizeti a felmerülő költségeket.

Az előre meghatározott költségvetési keret mellett meg kell határozni a projekt idö- és térbeli határait, melyekhez mint mérföldkövekhez igazodhatnak a résztvevők. Az idő- és térbeli meghatározás segíti a szervezőket abban is, hogy felmerjék, megbecsüljék a szükséges erőforrásokat, az önkéntesek számát.

Az első lépések után a projekt „fejlesztési” fázisa következik. A célmeghatározás alapján elkezdődhet a felkészítő anyagok 
összeállítása. Ezek kapcsán érdemes lehetőleg minél átláthatóbb és sokrétűinformációt adni az önkénteseknek, köznyelven, ismeretterjesztő módon leírni a szakterületet, miért fontos a kutatás, hogyan segíthetik az önkéntesek a projektet, mire számítanak a szakemberek, mely kritériumok teljesülése alapján mondható majd sikeresnek a projekt. Szerencsés esetben a projektben könyvtár és könyvtáros is részt vesz, a könyvtári közösségi pontra kerülő szóróanyagok mellett, különböző időpontokban célszerü előadásokat tartani, a könyvtár honlapján is felhívni az érdeklődők figyelmét a lehetőségekre. Amennyiben szükséges, a „fejlesztési” időszakban kell elkészülnie a projekthez használt egyedi szoftvernek, meg kell határozni az adatbevitel módszereit. Irásba kell foglalni a projekthez kapcsolódó protokollokat, etikai szabályzatot. Ebben az időszakban indul meg a toborzás és a szerteágazó marketing munka, amely egyszerre népszerüsíti a közösségi tudományos projektet, a szakterületet és a projektben harmadik félként résztvevő közgyüjteményt.

A projekt megvalósítási időszakában indul az önkéntesek felkészítése, ezek után az önkéntesek, sokszor a szakemberekkel együtt, a tudományos kutatási projektben leírtak alapján végzik a feladatot. Ennek az időszaknak lényeges, kihagyhatatlan része az önkéntesek munkáinak, az adott szakterület szakemberei által végzett, folyamatos ellenőrzése, és visszajelzés küldése az önkénteseknek. Egy közösségi tudományos projekt minden fél számára remek hírverési eszköz, ebben a fázisban a lehető legtöbb alkalommal és legtöbb helyen hírt kell adni a munkáról, a várható eredményekről, a részvevő önkéntesekről, a szakterület helyzetéről és a folyamatokat segítő könyvtárról.

Az elemzések és jelentések időszaka még nem a projekt lezárása. Sokszor ez az időszak hosszabb, mint az adatgyüjtés, ekkor készülnek el az adatelemzések, az eredmények összesítése, esetleg összehasonlítása egy előző projekt eredményeivel, publikálása és értelmezése. Fontos az önkéntesekkel való munka kapcsán kialakult tapasztalatok megfogalmazása és megosztása mind az önkéntesekkel, mind a szakemberekkel. A European Citizen Science Association 
által közreadott 10 alapelv 2. pontja szerint a közösségi tudományos projektek eredménye hiteles tudományos eredmény, amit még biztos sokan és sokáig megkérdőjeleznek a kutatók közül, éppen ezért elengedhetetlen az adott szakma elismert szakmai folyóirataiban nyílt hozzáféréssel publikálni, hangsúlyozva az önkéntesek szerepét és az általuk végzett munkafolyamatokat az egész kutatási projekten belül.

Mivel a közösségi tudomány a nyílt tudomány egyik összetevője, ezért minden esetben a gyüjtött adatokhoz, következtetésekhez szabadon hozzá kell férnie minden érdeklődőnek, akár jártas az adott szakterületen, akár nem.

A projektek lezárása egyértelműen egy összegzés, amelybe minden résztvevőt érdemes bevonni. Ezt sokszor egy-egy konferenciával, kiállítással szokták megvalósítani, ami újabb lehetőséget biztosít a népszerüsítésnek. Más-más perspektívából látja a projekt eredményét a kutató, az önkéntes és a könyvtáros vagy mediátor. Törekedni kell rá, hogy minden résztvevő csoport megszólaljon egy beszámoló kapcsán. A közösségi tudományos projektek nemcsak tudományos szempontból fontosak, érdemes levonni a közösségre gyakorolt hatását is a közös munkának.

\section{HAZAi jó GYAKORLATOK}

A közösségi régészet mint fogalom a 2000 -es évek legelején jelent meg a nemzetközi szakirodalomban. Magyarországon az első közösségi régészettel foglalkozó cikk 2019-ben jelent meg, Rácz Tibor Ákos ${ }^{32}$ tollából. A Pest Megyei Ferenczy Múzeum Központ régészei 2010 óta szerveznek olyan tervásatásokat, melyeken nemcsak régészek, muzeológusok, egyetemi hallgatók vesznek részt, hanem amatőrök is, önkéntes alapon. Az évek során sok tapasztalatra tettek szert. 2019-ben Közösségi Régészet Egyesület néven először megyei hálózat kialakítását

32 Rácz Tibor Ákos, Közösségi Régészet: egy új kutatási eljárás születése, MuzeumCafe, 72(2019), 149-158. https://epa.oszk.hu/03300/03343/00015/pdf/EPA03343_ muzeumcafe_72_149-158.pdf (utolsó megtekintés: 2021. 07. 04.) 
kezdték meg, mely mára országossá nőtte ki magát. Az egyesület célja, hogy a fémkeresős kincsvadászok figyelmét egy sokkal tágabb cél felé fordítsák, a régészeti lelőhelyek örökségvédelmi értékére és a számos régészeti lelet kulturális értékére.

A Közösségi Régészet Egyesület felismerte a közösségben rejlő erőt és lehetőséget, kihasználja a helyi értékek feltárására és megőrzésére irányuló helyi érdekeket. Az elmúlt időszakban önkéntesnek jelentkezők száma szemmel láthatóan megugrott, egyre szerteágazóbb tevékenységekbe lehet bevonni az önkénteseket, nemcsak az ásásba, de a tervezésbe és a döntéshozatalba is. A hobbi fémkeresők csoportjából áttevődött a hangsúly egy-egy lelőhely teljes régészeti feltárására.

Az Egyesület honlapot ${ }^{33}$ üzemeltet, mely sok szempontból mutatja az elmúlt időszak sikereit, a kiforrott együttműködés kereteit. A honlap nemcsak az egyesület tevékenységét, a csatlakozás mikéntjét, tisztviselőit mutatja be, hanem az önkéntesek is lehetőséget kapnak publikálásra, élménybeszámolóra, ezáltal is népszerűsítve a közösségi tudományos projektek sikereit, előnyeit és a bennük rejlő lehetőséget. A honlapon elérhető az aktuális feltárásról egy rövid képes beszámoló, a lezárt kutatásoknál pedig olvasható a résztvevő önkéntesek névsora. $\mathrm{Az}$ értékmentés és értékteremtés az Egyesület stratégiai célkitűzése. Az ásatások során felszínre került leletek, kincsek restaurálására nem minden esetben van anyagi lehetősége a területileg illetékes múzeumnak. Az Egyesület honlapján a „Fogadj örökbe” címszó alatt egy-egy lelet fényképe mellett látható, hogy milyen költséggel jár a restaurálása, amelyre szintén adakozni lehet. A finanszírozók nevét - amennyiben hozzájárulnak -szintén feltüntetik a honlapon.

Az Egyesület egyik kezdeményezése egy nyílt hozzáférésű folyóirat elindítása, LANCEA REGIS címen, melyben közösségi régészeti projekteket vezető régészek által írt szakmai cikkek vannak, egy-egy feltárás és kutatás menetéről.

33 Közösségi Régészeti Egyesület honlapja www.kozossegiregeszet.hu (utolsó megtekintés: 2021. 03. 14.) 
$\mathrm{Az}$ Egyesület rendszeresen tart workshopot, tréninget az egyesületi tagoknak és érdeklődőknek. Az eleinte megyei szintű mozgalom iránt szakmai körökben is egyre nagyobb érdeklődés tapasztalható, már minden megyéből csatlakozott régész az egyesület tevékenységéhez. $\mathrm{Az}$ egyesület régészei nagy hangsúlyt és energiát fektetnek az önkéntesek megtartásába, motiválásába, szerephez juttatására. Folyamatosan lehetőséget biztosítanak az önkénteseknek az ásatásokról szóló beszámolók megírására és a workshopokon is állandó előadók. Az önkéntesek csatlakozása szabályozott, az egyesület alapelveit, mely nagyban hasonlít a múzeumi etikai kódexre, a kulturális örökség múzeumi megőrzését, minden csatlakozónak el kell fogadni. A lemorzsolódás természetes folyamat, egy-egy terület feltárásánál jellemzően a helyi önkéntesek száma megnő, azonban, sajnos, arra is volt példa az elmúlt időszakban, hogy egy-egy önkéntest kizártak az egyesületből az etikátlan viselkedése miatt.

A Közösségi Régészeti Egyesült a közösségi tudomány jó példája, minden fórumot és lehetőséget megragadnak munkájuk láttatására és eredményeik elismertetésére. Munkájuk és a feltárt kincsek bemutatására 2021. június 19-én nyílt kiállítás Szentendrén.

A múzeumi területen szintén kimagasló a szentendrei Skanzen közösségi tudományos tevékenysége, annak ellenére, hogy a kifejezést nem használják. A koronavírus-járvány okozta első lezárás alatt, 2020 tavaszán hirdette meg a Határtörténetek felhívását a szabadtéri múzeum. A projekt a Határtalan Skanzen ${ }^{34}$ tematikus évhez kapcsolódott, mely a Trianon utáni időszak hétköznapjaival foglalkozott. A projekt során a látogatók által elküldött képeket, történeteket gyüjtötték az elmúlt száz év határátlépéséről, így az oral history műfajt vegyítették a Citizen Science-szel. Az eredmény nemcsak egy virtuális kiállítás, hanem a kordokumentumok alapján egy széles társadalmi réteg életstílusát, hozzáállását, szociális helyzetét lehet rekonstruálni szakemberek bevonásával.

34 Szabadtéri Néprajzi Múzeum: Skanzen honlapja https://skanzen.hu/hu/askanzen/projektek/hatartortenetek-felhivas (utolsó megtekintés: 2021. 03. 14.) 
A szentendrei Skanzen az elmúlt időszakban egyre inkább társadalmasítja a kiállításokat, számos felhívást tesznek közzé, a múzeum látogatói formálják a kiállítások tematikáját. A Cselekvő Közösségek 2016-2019 között futó EFOP 35 pályázat keretében országos programot indítottak a Skanzen vezetésével, mely kifejezetten a társadalmi aktivitás növelésére, a közösségi szerepvállalás erősítésére fókuszált, hogyan tudják a közgyüjtemények céltudatosabban és hatékonyabban bevonni az adott közösséget a saját munkájukba. A projekt eredménye sok szempontból a jövőben mutatkozik meg, mennyire lesz hatékony a projekt során kialakított országos kulturális közösségfejlesztő mentorhálózat. A Cselekvő Közösségek projekt tanulságait azonban mindenképpen érdemes megvizsgálni, hiszen éppen az aktív közösség az alapja a közösségi tudományos projekteknek.

A külföldi példák alapján megállapítható, hogy általánosságban a természettudományos projektek többségben vannak. Mivel hazánkban sem az önkéntességnek, sem a közösségi tudománynak, de még a nyílt tudománynak és a nyílt hozzáférésnek sincs jogszabályi háttere vagy akár civil kezdeményezésen alapuló egyesülete, ezért igazából nem is lehet számszerüsíteni a megvalósult vagy müködő közösségi tudományos projekteket. Hagyatkozva a külföldi aggregátorokra, az egyesületek által közzétett projektekre és a napi tapasztalatainkra, mondhatjuk, hogy hazánkban is jelentős számban vannak és népszerűek a természettudományos projektek. Az önkéntesek bevonásával történő tudományos projektek legkiemelkedőbb hazai példája a Nemzeti Biodiverzitás-monitorozó Rendszer keretein belül kialakított vadonleso.hu oldal, melyet magyarországi példaként említ a legfrissebb nemzetközi szakirodalom is. ${ }^{36}$ A Nemzeti Biodiverzitás-monitorozó Rendszer a Vidékfejlesztési Minisztérium, Természetmegőrzési

35 https://skanzen.hu/hu/a-skanzen/intezmenyeink/cselekvo-kozossegek(utolsó megtekintés: 2021. 03. 14.) https://cselekvokozossegek.hu/(utolsó megtekintés: 2021. 03. 14.)

36 The Science of Citizen Science, ed. Vohland, Katrin, Land-Zandstra, Anne, Ceccaroni, Luigi, Lemmens, Rob, Perelló, Josep, Ponti, Marisa, Samson, Roeland, Wagenknecht, Katherin, Springer, 2011, 41. https://doi.org/10.1007/978-3-030-58278-4 (utolsó megtekintés: 2021. 03. 14.) 
Főosztály által koordinált program, melynek keretében hosszútávú megfigyeléseket végeznek, hogy minél kevesebb állat- és növényfaj kerüljön veszélyeztetett helyzetbe. A vadonleso.hu ${ }^{37}$ weboldalon és a hozzá kapcsolódó mobilalkalmazáson az önkéntesek a közvetlen környezetükben észlelt növényeket és állatokat tudják regisztrálni. A honlap felsorolja, bemutatja és leírást ad 10 állatfajról és 8 növényről. A honlapon regisztrált önkéntesek térképen jelölhetik be az adott faj aktuális előfordulását, és részletes adatlapot töltenek ki. A feltöltött adatok szakmai ellenőrzést követően egy hivatásos természetvédelem adatbázisába, a Természetvédelmi Információs Rendszerbe (TIR) kerülnek, ezzel az önkéntesek nagy segítséget nyújtanak egy-egy faj megőrzésében. A közösségi tudományos projekt minden kritériumának megfelel a Vadonleső program, önkénteseikről is rendszeresen megemlékeznek, a honlapjukon közzéteszik egy-egy időszak legtöbbet feltöltő megfigyelőt.

Számos közösségi tudományos projekt éppen azért indul el, mert az érdeklődők, akár adott település, közösség állampolgárai kezdeményezik a kutatást. Ilyen a 2021. júniusában Eger környékén élők összefogása, hogy feltárják a Nagy-Eged hegyen lévő egykori kápolnát ${ }^{38}$. A projektben nyugdíjas matematikatanár, művészettörténész, régészek, levéltárosok, a Dobó István Vármúzeum és az Egererdő Zrt. több munkatársai is részt vesznek.

A Kézai Simon Program pedig már állami kezdeményezés alapján jött létre a Digitális Jólét programhoz kapcsolódva. „A Program küldetése olyan országos mozgalom létrehozása, amelynek célja digitálisan megőrizni a régi, analóg technológiával fotókon rögzített emlékeket és családi történeteket. A Program keretén belül a fényképek és dokumentumok digitalizálását, valamint online albumba rendezését a fotók tulajdonosai webes felületen, ingyenes mobilapplikáció

37 Vadonleső honlap https://vadonleso.hu/ (utolsó megtekintés: 2021. 03. 14.)

38 Elfeledett titkokat rejt az egri Nagy-Eged hegyi kápolna, Magyar Nemzet, 2021. 06. 16. https://www.heol.hu/kozelet/helyi-kozelet/elfeledett-titkokat-rejt-az-egrinagy-eged-hegyi-kapolna-3719399/(utolsó megtekintés: 2021. 07. 03.) 
segítségével, illetve az ország 25 pontján a Digitális Jólét Program Hálózat Kézai Pontjain, könyvtárakban, levéltárakban tudják elvégezni ingyenesen 100 kép erejéig. A Program szeretné ezeket az emlékeket, valamint a hozzájuk kapcsolódó történeteket megőrizni az utókor számára, a kollektív emlékezet részévé tenni, ezáltal lehetővé téve a nemzettörténeti elemzések kiegészítését, kutatások támogatását." ${ }^{39}$

Ma már az önkéntesek „alkalmazása”, főleg a kulturális intézményekben teljesen bevett és megszokott dolog. Azonban látnunk kell, hogy a közösségi tudomány más, eltér az általános önkéntesi munkától. Minden esetben konkrét projektekben gondolkozunk, mely meghatározott ideig tart, mindig az adott szakterület szakembere irányítja és ellenőrzi az adatokat, munkafolyamatot. Az önkéntesek lelkesedése kézzel fogható, hiszen szabadidejüket áldozzák fel egy adott ügy érdekében. A résztvevő önkéntesek életkorát vagy korfáját ugyan még egy közösségi tudományos cikk sem dokumentálta, de az ismert projektekbe jellemzően a gyerekek/fiatalok és a nyugdíjasok jelentkeznek önkéntesnek, akiknek az időbeosztása és elfoglaltsága lehetővé teszi a rugalmasságot. Az önkéntesek a csatlakozással egy új közösség tagjai lesznek, akár a valóságban, akár virtuálisan találkoznak, befolyással vannak egymásra. A résztvevő önkéntesek érdeklődőek, nyitottak az új ismeretekre, első kézből kaphatnak információt a kutatásról. A visszacsatolások alapján érezhetik, hogy a társadalom, közösség hasznos tagjai, a közösségi tudományos projektben való részvétellel nemcsak saját ismereteik gyarapodnak, hanem maguk is értéket teremtenek.

39 Kézai Simon Program honlapja https://kezai.hu/about (utolsó megtekintés: 2021. 07. 04.) 


\section{FelHASZnÁlt IRODALOM}

Bonter, David N., Cooper, Caren B., Data validation in citizen science: a case study from Project FeederWatch, Frontiers in Ecology and the Environment, Vol. 10, issue 6. Forrás: https://doi.org/10.1890/110273

Causer, Tim, Grint, Kris, Sichani, Anna-Maria, Terras, Melissa, 'Making such bargain': Transcribe Bentham and the quality and cost-effectiveness of crowdsourced transcription, Digital Scholarship in the Humanities, Vol. 33, Issue 3, September 2018, 467-487.

Forrás: https://doi.org/10.1093/llc/fqx064

Citizen Science, Innovation in Open Science, Society and Policy, ed. НескеR, Susanne, Haklay, Muki, Bowser, Anne, Makuch, Zen, Vogel, Johannes, Bonn, Aletta, London, UCL Press, 2018, 580.

Forrás: https://www.uclpress.co.uk/products/107613

Conen, Cynthia M., Cheney, Liz, Khue Duong, Lea, Ben, Unno, Zoe Pettway, Identifying Opportunities in Citizen Science for Academic Libraries, Issues in Science and Technology Librarianship, 2015 winter, (79). Forrás: https://doi.org/10.5062/F4BR8Q66

Holl András, Amatőr kibertudomány, Természet Világa, 201l. december, 571-574.

Ignat, Tiberius et al., Merry work: libraries and citizen science, Insights, 31(2019), 35. Forrás: http://doi.org/10.1629/uksg.431

Ignat, Tiberius, Cavalier, Darlene, Nickerson, Caroline, Citizen Science and Libraries: Waltzing towards a collaboration, Mitteilungen der Vereinigung Österreichischer Bibliothekarinnen und Bibliothekare, 72(2019), 328-336. Forrás: https://doi.org/10.31263/voebm.v72i2.3047 
Monok István, Könyvtári(?) problémák, Budapest, MTA KIK, 2020 (A Magyar Tudományos Akadémia Könyvtárának közleményei. Új sorozat, 41.)

https://doi.org/10.36820/MTAKIK.KOZL.2020.KONYVTAR

Moyle, Martin, Tonra, Justin, Wallace, Valerie, Manuscript Transcription by Crowdsourcing: Transcribe Bentham, LIBER Quarterly, 20(3-4), 347-356.

Forrás: http://doi.org/10.18352/lq.7999

RÁcz Tibor Ákos, Közösségi régészet: Egy új kutatási eljárás születése, MúzeumCafé, 72, 4(2019), 13. évf., 148-157.

Forrás: https://epa.oszk.hu/03300/03343/00015/pdf/EPA03343_

muzeumcafe_72_149-158.pdf

Wiggins, Andrea, Newman, Greg, Stevenson, Robert D., Crowston, Kevin, Mechanisms for Data Quality and Validation in Citizen Science, 2011 IEEE Seventh International Conference on e-Science Workshops, Stockholm, 2011, 14-19.

Forrás: https://doi.org/10.1111/cobi.12706 


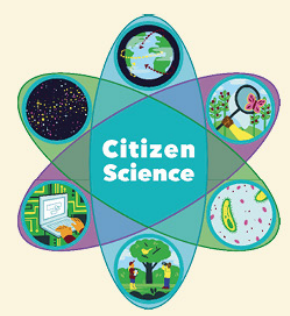

KÖZÖSSÉGI TUDOMÁNY

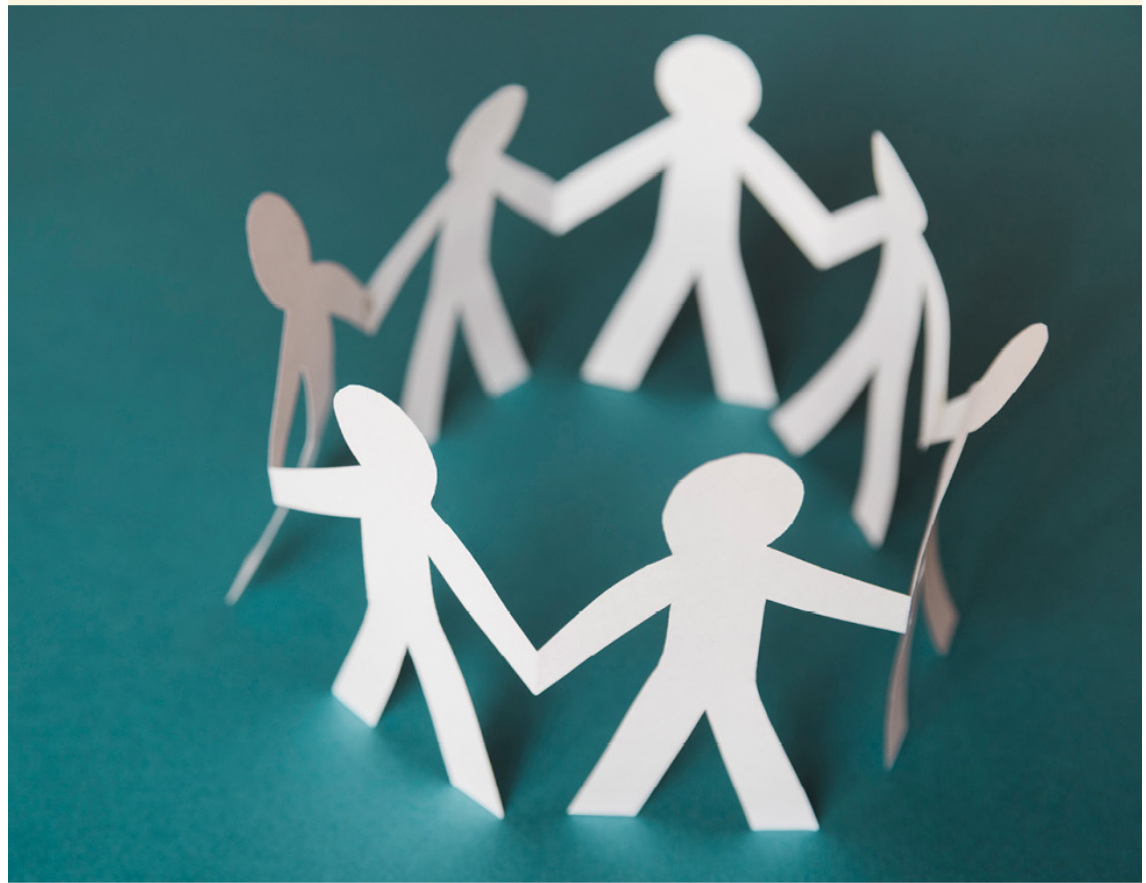




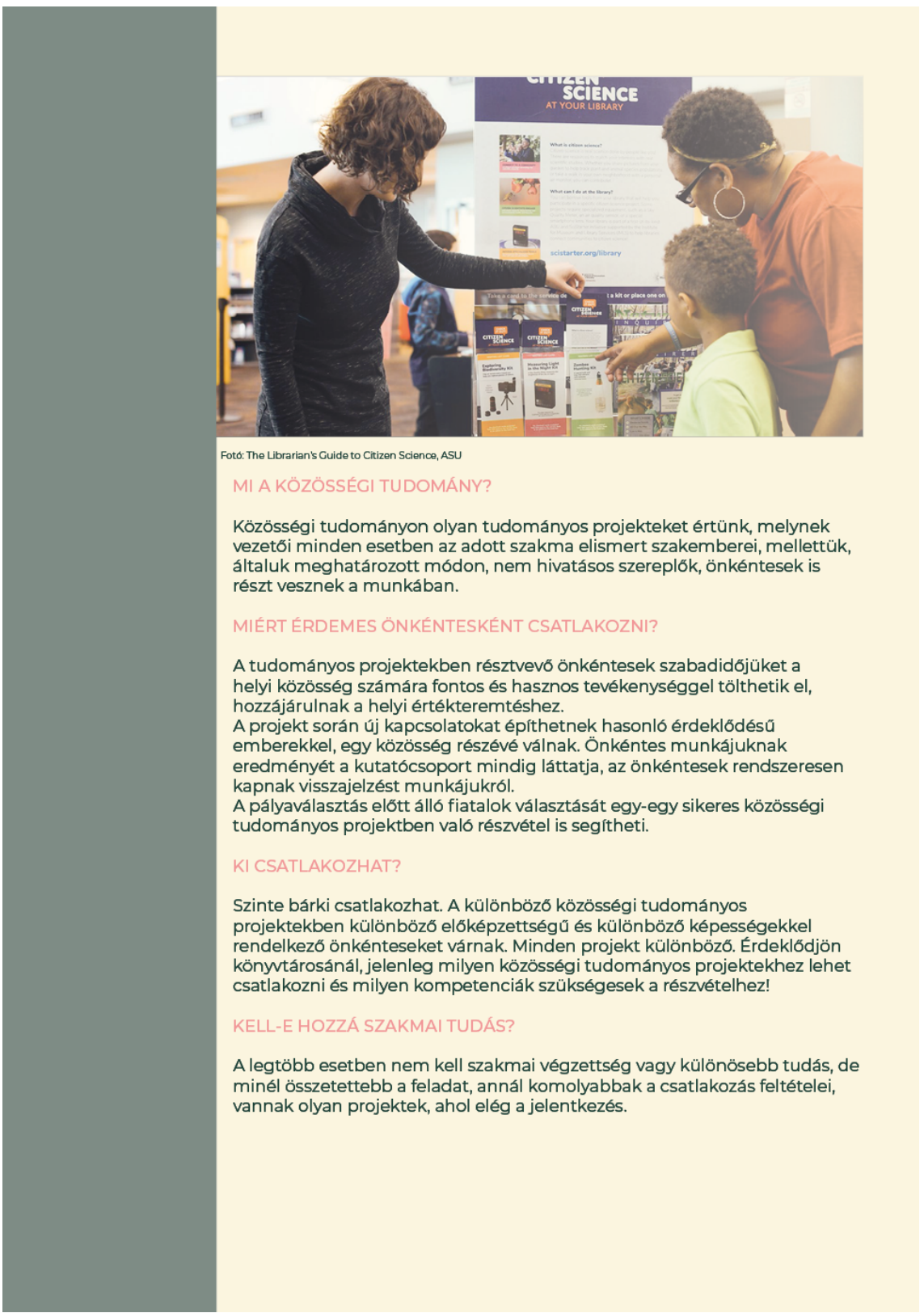




\section{MILYEN JUTTATÁSOKAT KAPHATOK?}

Általában a közösségi tudományos projektek költségvetése szükös, nem jellemzó, hogy bármilyen juttatást kapnának az önkéntesek, azonban a projektben résztvevơk mindig kapnak visszajelzést a munkájukról. A közösségi tudományos projektekben részt vevő önkénteseket köszönetnyilvánítás és elismerés illeti meg a projekt eredményeinek közzétételekor és a publikációkban.

\section{MILYEN KÖTELESSÉGEIM VANNAK ÖNKÉNTESKÉNT?}

\begin{abstract}
A közösségi tudományos projekt vezetōje gondoskodik a tevékenység ellátásához szükséges irányításról, tájékoztatásról, amennyiben szükséges, az önkéntesek képzéséről. A projekt vezetóje által meghatározott etikai és szakmai szabályokat be kell tartani a munka eredményessége és a közösségi tudományos projektben résztvevő́k érdekében. A közösségi tudományos projektekhez kapcsolódók nyilatkoznak a szabályok, elö́rások, módszerek betartásáról.
\end{abstract}

\section{HOGYAN CSATLAKOZHATOK?}

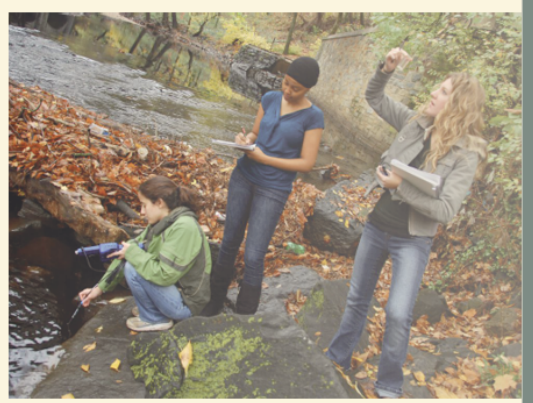

Foto: Jackie Karsten, National Geographic

A különbözó közösségi tudományos projektek más és más csatlakozási feltételt szabhatnak. Érdeklödjön könyvtárosánál a lehetőségekről!

\section{HOGYAN VESZNEK RÉSZT A KÖNYVTÁRAK A KÖZÖSSÉGI TUDOMÁNYBAN?}

A könyvtárak a kutatócsoport és az önkéntesek között moderátorként, információs bázisként vesznek részt a projektekben. A programhoz kapcsolódó könyvtárakban az olvasókkal kapcsolatot tartó könyvtárosok tájékoztatást nyújtanak a településen, régióban elérhetớ közösségi tudományos projektekről, összekötik az érdeklödóket és a szakembereket. Sok esetben a könyvtárosok tartják a projekthez kapcsolódó felkészító elóadásokat, információt és segítséget nyújtanak az önkénteseknek. A könyvtáraknak lehető́ségük van saját közösségi tudományos kutatást indítani, ekkor a könyvtár szakemberei a kutatás vezetói.

\section{MIÉRT ÉRI MEG A KUTATÓKNAK KÖZÖSSÉGI TUDOMÁNYOS PROJEKTET SZERVEZNI?}

A közösségi tudományos projektek legfóbb haszna, hogy jelentős számú érdeklődőt lehet megszólitani, sok önkéntessel dolgozhatnak a kutatók, f́gy általában egyegy megfigyelés, kísérlet, projekt hamarabb befejezódik, és/vagy sokkal nagyobb merítésre tehetnek szert. Minél többen csatlakoznak a projekthez, annál többen beszélnek róla, az adott tudományterület népszerüsége és ismertsége nó. Az önkéntesek bekapcsolásával egy új, megbízható reklámfelület nyílik a szakma számára. 


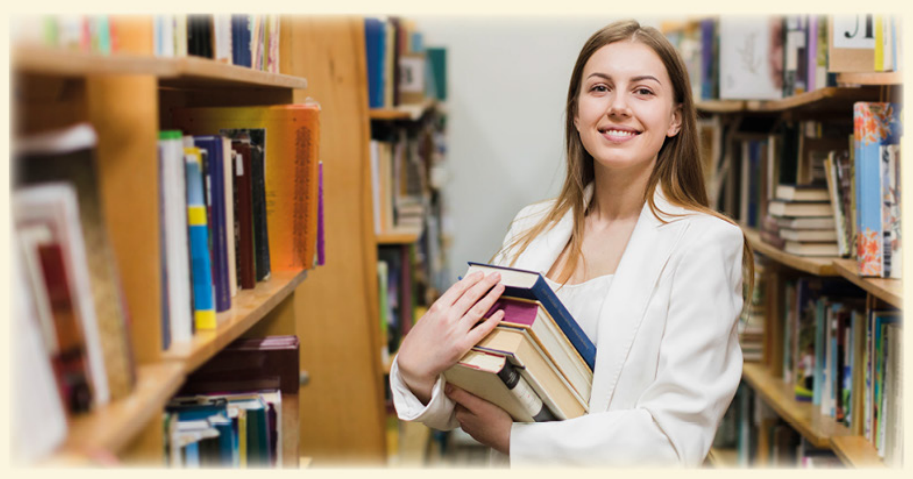

Amennyiben felkeltettük az érdeklődését, látogassa meg a könyvtár honlapját, kérdezze meg könyvtárosát a helyi, regionális közösségi tudományos projektekről!

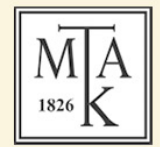

Borttofotok: Freepikcom 


\section{Open Science \\ NYÍLT TUDOMÁNY MAGYAR SZEMMEL}


A Magyar Tudományos Akadémia Könyvtárának Közleményei Publicationes Bibliothecae Academiae Scientiarum Hungaricae

$45(120)$
UJ SOROZAT

SOROZATSZERKESZTő

GaÁlné Kalydy Dóra 


\section{Open Science \\ NYÍLT TUDOMÁNY MAGYAR SZEMMEL}

Magyar Tudományos Akadémia

KöNYVTÁr ÉS InFORMÁcIÓs KözPONT

BUDAPEST 2021 


\author{
Szerkesztette \\ GaÁlné Kalydy DóRA \\ Anyanyelvi lektor \\ MóNOK MÁRIA \\ Az irodalomjegyzékeket készítette \\ BudAI-KirÁLY TÍmEA \\ Tipográfia és tördelés \\ VAs ViKTória \\ ISBN 978-963-7451-73-7 \\ ISSN 0133-8862 \\ DOI 10.36820/MTAKIK.KOZL.2021.OpenS
}

Felelős kiadó: az MTA Könyvtár és Információs Központ főigazgatója

Nyomta és kötötte az Alföldi Nyomda Zrt., Debrecen

Felelős vezető: GYöRGy GÉzA vezérigazgató

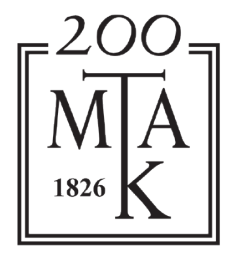

Megjelent a Nemzeti Kulturális Alap támogatásával

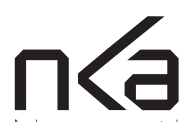

Nemzeti Kulturális Alap 


\section{TARTALOM}

\section{Monok István}

Cui bono, seu cui prodest?

Holl András

A tudományos szakkönyvtárak és a nyílt tudomány

(Open Science)

GaÁlnÉ Kalydy Dóra

A kiadókkal kötött Read and Publish szerződések, és a nyílt hozzáférésű publikálás hazai lehetőségei

Soós SÁndor, Kiss AnNA

Az „Open Access-előnyök" megnyilvánulása

a hazai tudásprodukcióban: bibliometriai hatásvizsgálat

61

\section{GaÁlné Kalydy Dóra}

A közösségi tudomány

\section{Tiberius Ignat}

What motivates us to develop the

Focus on Open Science series?

\section{Hoczopán Szabolcs, Molnár Tamás}

Az egyetemi könyvtárak szerepe a nyílt tudomány

mozgalom elterjesztésében

\section{Holl ANDrás}

Az MTA KIK gyakorlata a nyílt tudomány támogatásában $\quad 161$

A kötetben szereplő tanulmányok szerzői

A Magyar Tudományos Akadémia Könyvtárának

Közleményei, Új Sorozat közelmúltban megjelent kötetei 